\title{
The Beneficial Effects of Principal Polyphenols from Green Tea, Coffee, Wine, and Curry on Obesity
}

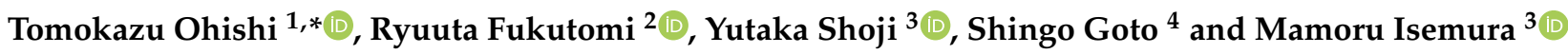 \\ 1 Institute of Microbial Chemistry (BIKAKEN), Numazu, Microbial Chemistry Research Foundation, \\ Shizuoka 410-0301, Japan \\ 2 Quality Management Div. Higuchi Inc., Minato-ku, Tokyo 108-0075, Japan; fukutomi_ryuuta@mac.com \\ 3 Graduate School of Integrated Pharmaceutical and Nutritional Sciences, University of Shizuoka, \\ Shizuoka 422-8526, Japan; yutaka_shoji@yahoo.co.jp (Y.S.); isemura@u-shizuoka-ken.ac.jp (M.I.) \\ 4 Division of Citrus Research, Institute of Fruit Tree and Tea Science, National Agriculture and Food Research \\ Organization (NARO), Shimizu, Shizuoka 424-0292, Japan; gotos@affrc.go.jp \\ * Correspondence: ohishit@bikaken.or.jp; Tel.: +81-55-924-0601
}

check for

updates

Citation: Ohishi, T.; Fukutomi, R.; Shoji, Y.; Goto, S.; Isemura, M. The Beneficial Effects of Principal Polyphenols from Green Tea, Coffee, Wine, and Curry on Obesity. Molecules 2021, 26, 453. https:// doi.org/10.3390/molecules26020453

Academic Editor: Saverio Bettuzzi Received: 23 December 2020 Accepted: 13 January 2021 Published: 16 January 2021

Publisher's Note: MDPI stays neutral with regard to jurisdictional clai$\mathrm{ms}$ in published maps and institutional affiliations.

Copyright: (C) 2021 by the authors. Licensee MDPI, Basel, Switzerland. This article is an open access article distributed under the terms and conditions of the Creative Commons Attribution (CC BY) license (https:// creativecommons.org/licenses/by/ $4.0 /)$.

\begin{abstract}
Several epidemiological studies and clinical trials have reported the beneficial effects of green tea, coffee, wine, and curry on human health, with its anti-obesity, anti-cancer, anti-diabetic, and neuroprotective properties. These effects, which have been supported using cell-based and animal studies, are mainly attributed to epigallocatechin gallate found in green tea, chlorogenic acid in coffee, resveratrol in wine, and curcumin in curry. Polyphenols are proposed to function via various mechanisms, the most important of which is related to reactive oxygen species (ROS). These polyphenols exert conflicting dual actions as anti- and pro-oxidants. Their anti-oxidative actions help scavenge ROS and downregulate nuclear factor- $\mathrm{kB}$ to produce favorable anti-inflammatory effects. Meanwhile, pro-oxidant actions appear to promote ROS generation leading to the activation of 5'-AMP-activated protein kinase, which modulates different enzymes and factors with health beneficial roles. Currently, it remains unclear how these polyphenols exert either pro- or anti-oxidant effects. Similarly, several human studies showed no beneficial effects of these foods, and, by extension polyphenols, on obesity. These inconsistencies may be attributed to different confounding study factors. Thus, this review provides a state-of-the-art update on these foods and their principal polyphenol components, with an assumption that it prevents obesity.
\end{abstract}

Keywords: polyphenols; epigallocatechin-3-O-gallate; chlorogenic acid; resveratrol; curcumin; obesity; reactive oxygen species; $5^{\prime}$-AMP-activated protein kinase; nuclear factor- $\mathrm{kB}$; randomized controlled trial

\section{Introduction}

Plant polyphenols are often found in beverages such as tea, wine, and coffee and in vegetables and fruits such as turmeric, onions, broccoli, apples, berries, citrus fruits, and plums [1].

Green tea is produced from leaves of the Camellia sinensis plant; a cup of green tea brewed from $2.5 \mathrm{~g}$ tea leaves has been reported to contain 240-320 mg catechins, of which (-)-epigallocatechin-3-O-gallate (EGCG, Figure 1) accounts for 60\%-65\% [2,3]. Black tea is similarly produced from these leaves by intrinsic enzymatic processing and microorganisms during which catechins are polymerized to generate lower EGCG levels.

Coffee contains approximately 2000 different chemicals; the major polyphenols are chlorogenic acid (CGA, Figure 1) and its derivatives, which account for approximately 3\% $w / w$ of the roasted coffee powder [2-4]. A single cup of coffee may contain 20-675 mg CGA [3].

Resveratrol (RSV, 3,4',5-trihydroxystilbene, Figure 1) is often derived from several plant sources, including grapes, peanuts, and berries, and it exists in two isomeric forms: 
cis- and trans-RSV. Trans-RSV (defined here as RSV, Figure 1) is naturally found in grape skin and in the leaf epidermis of the grape vine and is the main RSV form in red grape juice $(3.38 \mathrm{mg} / \mathrm{L})$ [1,4]. Daily RSV intake may be in the order of several $\mathrm{mg} /$ day [5].<smiles>O=C(O[C@H]1Cc2c(O)cc(O)cc2O[C@@H]1c1cc(O)c(O)c(O)c1)c1cc(O)c(O)c(O)c1</smiles>

Epigallocatechin-3-O - gallate (EGCG)<smiles>O=C(/C=C\c1ccc(O)c(O)c1)OC1CC2OC(=O)C(O)(C1)C(O)C2O</smiles>

Chlorogenic acid (CGA)<smiles>Oc1ccc(/C=C/c2cc(O)cc(O)c2)cc1</smiles>

Resveratrol (RSV)<smiles>COc1cc(/C=C/C(=O)/C=C(O)/C=C/c2ccc(O)c(OC)c2)ccc1O</smiles>

Curcumin (CRC)

Figure 1. Chemical structures of epigallocatechin-3-O-gallate (EGCG), chlorogenic acid (CGA), resveratrol (RSV), and curcumin (CRC).

Curcumin (CRC, Figure 1) is a yellow pigment, an active component of the turmeric plant (Curcuma longa), and is widely used in cooking, cosmetics, dyes, and medicines $[1,6]$. In Asian populations, approximately $100 \mathrm{mg}$ CRC is consumed daily [1,4].

Several studies have shown that consuming tea, coffee, wine, and curry can be beneficial in fighting against various diseases including, cancer, obesity, neurodegenerative disorders, and diabetes. Their polyphenolic constituents are believed to contribute mainly to these effects as discussed in our previous reviews [1-3,6,7].

Thus, this review summarizes contemporary data from human epidemiological obesity studies on these polyphenols and discusses mechanistic aspects related to laboratory findings from cell and animal experiments.

\section{The Effects of Green Tea/EGCG on Obesity}

Epidemiological studies have suggested that green tea and its principal constituent, EGCG, exert beneficial effects on chronic diseases, including obesity [1-3,6].

\subsection{Observational Epidemiological Studies of Anti-Obesity Effects of Green Tea/EGCG}

Several observational human studies have indicated that tea or green tea consumption can exert beneficial effects on obesity. For example, a cross-sectional survey of 1210 epidemiologically sampled adults (569 men and 641 women) demonstrated that habitual tea drinkers (455 individuals were green or oolong tea consumers, and 18 were black tea consumers) for $>10$ years showed a $19.6 \%$ reduction in percent body fat and a $2.1 \%$ reduction in waist-to-hip ratios when compared with non-habitual tea drinkers [8]. 
Recent data from an epidemiological study with 6472 adult participants found that tea consumers had a lower mean waist circumference (WC) and lower body mass index (BMI) (25 vs. $28 \mathrm{~kg} / \mathrm{m}^{2}$ in men; $26 \mathrm{vs.} 29 \mathrm{~kg} / \mathrm{m}^{2}$ in women) than non-consumers [1].

However, a recent study on 3539 participants observed that green tea was not associated with visceral obesity or metabolic syndrome (MetS) [9]. Thus, further studies are required to elucidate the anti-obesity properties of green tea.

\subsection{Human Intervention Studies on the Effects of Green Tea/EGCG on Obesity}

Several intervention studies have reported the beneficial effects of green tea [10,11]. In a randomized controlled trial (RCT) on 35 subjects with obesity and MetS, patients were randomly assigned to a control (four cups of water/day), green tea (four cups/day), or green tea extract (GTE) (two capsules and four cups of water/day) group for 8 weeks [12]. As per the findings of this study, it showed that green tea and GTE significantly decreased body weight and BMI vs. controls at 8 weeks $(-2.5 \pm 0.7 \mathrm{~kg}$ and $-1.9 \pm 0.6$, respectively). These results further indicated the therapeutic effects of green tea catechins (GTCs) in improving MetS characteristics in obese patients.

A double-blind parallel multicenter trial in 240 subjects by Nagao et al. [13] observed that participants who consumed a GTC $583 \mathrm{mg}$ /day dose exhibited greater decreases in body weight, BMI, body fat ratio, body fat mass, WC, hip circumference, visceral fat area (VFA), and subcutaneous fat area when compared to those who consumed a GTC $96 \mathrm{mg} /$ day dose.

The anti-obesity benefits of green tea were also demonstrated in a meta-analysis of 24 human studies [14]. In total, 5 of the 11 trials in Eastern populations showed significant weight loss, ranging from $1 \mathrm{~kg}$ to $2 \mathrm{~kg}$, and 3 of the 13 trials also demonstrated notable weight loss ranging from $1 \mathrm{~kg}$ to $9 \mathrm{~kg}$.

In another RCT, 102 obese women were randomly divided into 2 groups: high-dose green tea group (EGCG, $856.8 \mathrm{mg} /$ day) and the placebo group. The results indicated that 12 weeks of high-dose green tea resulted in significant weight loss $(76.8 \pm 11.3 \mathrm{~kg}$ $75.7 \pm 11.5 \mathrm{~kg}$ ) and decreased BMI, WC, total cholesterol (TC) and plasma low-density lipoprotein (LDL) levels, without any adverse effects to participants [15].

In another RCT, 73 obese women were divided into two groups: group A received GTE supplements for the first 6 weeks, while group B received daily placebo. After 6 weeks of treatment and a 14-day washout period, groups A and B were switched to placebo treatment and GTE treatment mutually for 6 weeks. These results showed that GTE effectively increased leptin and reduced LDL levels in these women [16].

Individuals with Down syndrome traditionally experience higher obesity rates [17]. In a double-blind phase II clinical trial in 77 young adults with Down syndrome, the placebo group showed increased body weight and BMI, which were not noted in an EGCGtreated group. The effect of EGCG on body composition was mainly observed in males, with significant differences between EGCG and placebo groups after 12 months, for body weight (estimated adjusted mean difference (AMD): $-2.34,95 \%$ confidence interval (CI): $-4.21,-0.48$ ) and body fat (AMD: -1.23 , CI: $-2.43,-0.04$ ), suggesting that EGCGs were beneficial for weight management in patients with Down syndrome [18].

A recent systematic review and meta-analysis revealed that green tea supplementation had favorable effects on body weight (weighted mean difference (WMD): $-1.78 \mathrm{~kg}$, CI: $-2.80,-0.75$ ) and BMI (WMD: $\left.-0.65 \mathrm{~kg} / \mathrm{m}^{2}, \mathrm{CI}:-1.04,-0.25\right)$. The reduction in WC after green tea consumption was determined to be significant for subjects using green tea at $\geq 800 \mathrm{mg}$ /day (WMD: $-2.06 \mathrm{~cm}$ ) and treatment durations of $<12$ weeks (WMD: $-2.39 \mathrm{~cm}$ ). This dose-response observation indicated that green tea intake at $<500 \mathrm{mg} /$ day may reduce body weight over 12 weeks of treatment [19].

In contrast, several clinical trials failed to show body weight reduction via green tea consumption. A clinical trial in 151 participants aged 30-70 years showed that $1.8 \mathrm{~g} /$ day GTE consumption for 12 weeks did not lower body weight when compared with placebo, although a significant LDL-cholesterol (LDL-C) lowering effect was noted [20]. Data from 
an RCT of 937 healthy postmenopausal women who received decaffeinated GTE containing $843 \mathrm{mg}$ EGCG reported that GTE was not associated with reductions in terms of body weight, BMI, or WC; further, it did not alter energy intake or mean hormone concentrations for over 12 months [21].

\subsection{Laboratory Studies and Mechanisms of EGCG Action}

Obesity is often characterized by the excessive accumulation of triglycerides (TGs), which are hepatically synthesized from both fatty acids (FAs) and de novo lipogenesis. Fatty acid synthase (FASN) is a central enzyme in lipogenesis and is responsible for FA production. The enzyme has gained considerable attention as a potential therapeutic target for obesity and cancer [22,23]. Zhang et al. [24] found that GTE inhibited FASN activity from duck liver, with a half-maximal inhibitory concentration $\left(\mathrm{IC}_{50}\right)$ of $12.2 \mathrm{mg}$ dry weight/mL [25]. Similarly, Tian et al. reported that EGCG inhibited FASN, with an $\mathrm{IC}_{50}$ of $52 \mu \mathrm{M}$, mainly via interactions with the FASN $\beta$-ketoacyl reductase domain.

Using a high-fat diet (HFD)-induced mouse obesity model, Wolfram et al. [26] observed that 1\% $(w / w)$ TEAVIGO, which contains $97.69 \%$ EGCG, prevented HFD-induced increases in mouse body weight. The authors also showed that FASN and acetyl-CoA carboxylase (ACC) mRNA levels were markedly decreased in adipose tissue. ACC has been identified as a key lipogenesis enzyme [27] and is potentially an anti-obesity target [28].

Both FASN and ACC expressions have been positively regulated by upstream lipogenesis transcription factors, including CCAAT/enhancer-binding proteins (C/EBPs) [29], peroxisome proliferation-activated receptors (PPARs, especially PPAR $\gamma$ ) [30], and sterol regulatory element-binding proteins (SREBPs) [31]. Lee et al. demonstrated that $0.2 \%$ or $0.5 \%(w / w)$ EGCG can reduce body weight and the mass of several adipose tissues in a dose-dependent manner in an HFD-induced mouse obesity model [32]. These results indicated that EGCG lowered plasma TG and liver lipid levels. In the epidermal white adipose tissue of EGCG-treated mice, C/EBP, PPAR $\gamma$, and SREBP mRNA levels were observed to be significantly decreased [32].

5'-AMP-activated protein kinase (AMPK) has been identified as a metabolite-sensing protein kinase. Activated AMPK triggers beneficial physiological effects, including reductions in fat deposition. Ha et al. revealed that AMPK knockdown has upregulated fat-forming enzymes, including FASN, ACC, and stearoyl-CoA desaturase, which is another key enzyme of fat synthesis. These results suggest that activated AMPK inhibited fat synthesis by inhibiting lipogenesis [33]. Given that GTE and EGCG activated AMPK by inducing reactive oxygen species (ROS) generation [34,35], GTE and EGCG could improve body weight and lipid metabolism by activating AMPK through ROS generation. EGCG actions against lipogenesis and adipogenesis are shown in Figure 2.

Increased lipolysis can hydrolyze TGs and release free FAs, leading to anti-obesity effects. Treatment of pre-adipocyte 3T3-L1 cells with $10 \mu \mathrm{M}$ EGCG for $24 \mathrm{~h}$ has been found to decrease intracellular lipid accumulation. Under the same experimental conditions, increased glycerol levels in the medium were observed, and hormone-sensitive lipase (HSL) mRNA levels, which catalyze rate-limiting stages in the hydrolysis of stored TGs to monoacylglycerol and free FAs, were similarly increased [36].

Consistent with these findings, Wistar rats on an obesity induced 8-week cafeteria diet, and supplemented with GTE (500 mg/kg body weight at 5 days/week for 12 weeks), led to significant reductions in obesity indicators, e.g., hyperlipidemia, fat synthesis, body weight, and fat depots when compared with the control diet group. Importantly, repression of de novo lipogenesis in adipose tissue, reduced lipid droplets in the liver, and insulin resistance development in diet-induced obese rats were accompanied by AMPK activation [37]. Similarly, mice fed a HFD with EGCG (50 and $100 \mathrm{mg} / \mathrm{kg} /$ day) exhibited significantly increased HSL mRNA expression in white adipose tissue when compared with the HFD group, and AMPK activity was noted to increase in both subcutaneous and epididymal adipose tissues in these mice [38]. These results suggest that GTE/EGCG decreased obesity in rats and mice via AMPK activation (Figure 2). 
A recent study examining EGCG effects and mechanisms on lifespan extensions in obese rats demonstrated that median lifespans in control, HFD, and HFD + EGCG animals were 693, 599, and 683 days, respectively, indicating EGCG can restore shortened lifespans mediated by HFD [39]. EGCG also reduced inflammation and oxidative stress associated with aging in HFD-induced rats. EGCG significantly decreased blood circulating interleukin (IL)-6, tumor necrosis factor- $\alpha$ (TNF)- $\alpha$, ROS, and superoxide dismutase (SOD) levels. EGCG also increased the expression of sirtuin-1 (SIRT1), catalase, fatty acid-binding protein-1, glutathione S-transferase (GST)-A2, and acyl-CoA synthetase-1, but significantly decreased nuclear factor (NF)- $\mathrm{kB}, \mathrm{ACC}-1$, and FASN expressions at the liver. These findings are represented by molecular events in Figure 2.

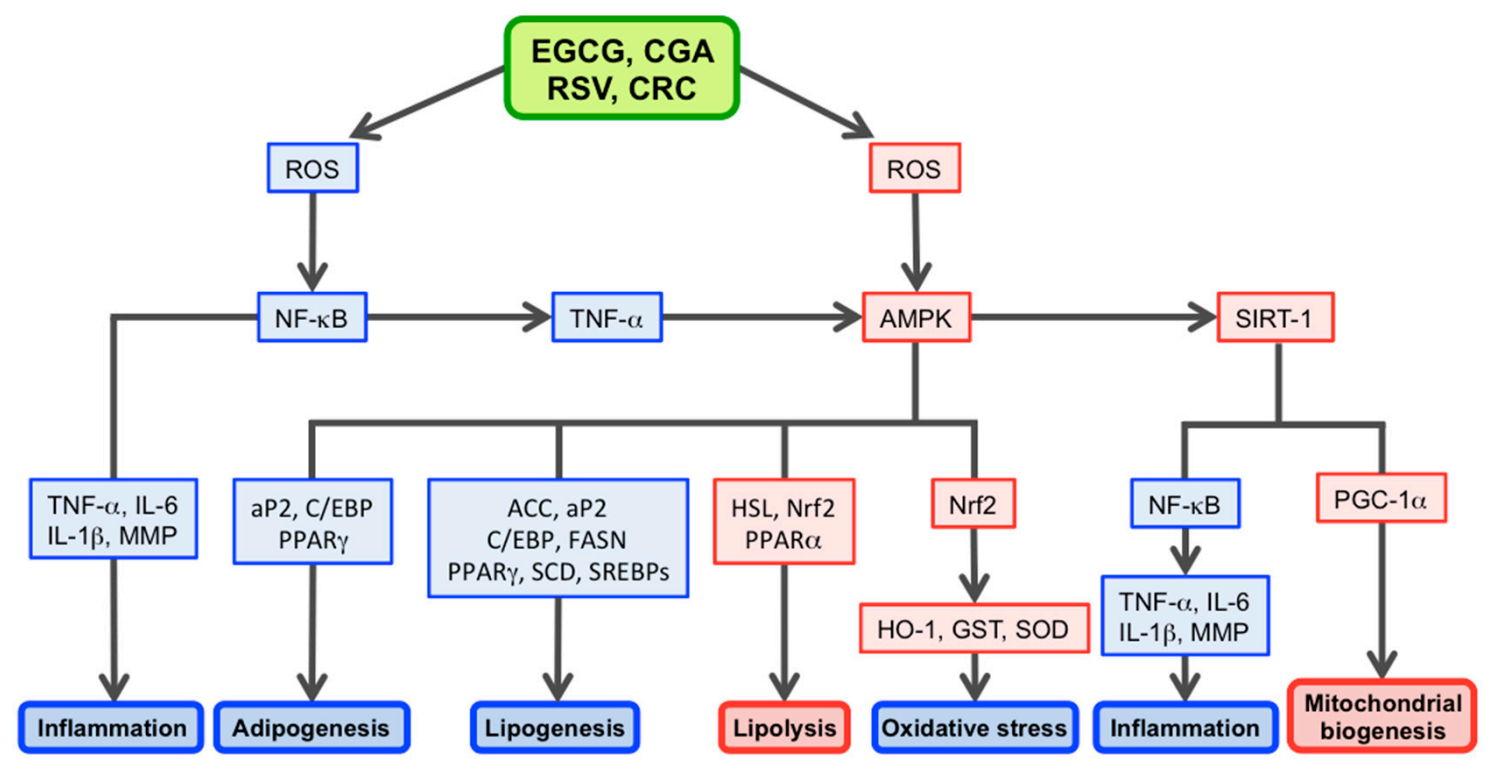

Figure 2. Potential anti-obesity mechanisms whereby EGCG, CGA, RSV, and CRC exert anti-obesity effects by scavenging/downregulating ROS. Red boxes represent upregulation/stimulation, whereas blue boxes represent downregulation/suppression.

It has been suggested that GTE regulates $\beta$-oxidation enzymes, which are one of the indices for FA burning promotion and are activated by PPAR $\alpha$ signaling [40,41]. Sae-Tan et al. [42] demonstrated that $0.32 \%$ dietary EGCG can reduce the body weight of HFDinduced mice, causing a 1.4-1.9-fold increase in PPAR $\alpha$ mRNA levels when compared to HFD controls.

In mice fed with diets containing either low fat (5\% TG), high fat (30\% TG), or high fat supplemented with $0.1 \%-0.5 \%(w / w)$ GTC for 11 months, Murase et al. [43] observed that GTC significantly reduced HFD-induced body weight gains and visceral and liver fat accumulation and prompted the development of hyperinsulinemia and hyperleptinemia. GTC supplementation for 1 month increased hepatic mRNA expression levels of acyl-CoA oxidase and medium chain acyl-CoA dehydrogenase, as well as $\beta$-oxidation activity.

It is also possible that EGCG may have exerted its anti-obesity effects by reducing lipid uptake and transport. The multi-ligand receptor, cluster of differentiation 36 (CD36), has been determined as a key transmembrane protein implicated in lipid uptake and transport [44]. EGCG decreased TCs and TGs in mice given 1,3-dichloro-2-propanol (1 mg/kg body weight/day), which is an inducer of oxidative stress. EGCG dramatically increased the expression of phosphorylated AMPK at Thr172 and lowered CD36 expression [45]. CD36 has also been deemed essential for lipoprotein binding at the liver [46]. Therefore, decreased CD36 expression induced by EGCG may be related to changes in blood lipid profiles [45]. Thus, EGCG inhibition of CD36 via AMPK activation may contribute to its anti-obesity effects [47]. 


\section{The Effects of Coffee/CGA on Obesity}

Coffee and CGA have been determined to exert anti-obesity effects in humans [48], with several observational and experimental epidemiological studies supporting this hypothesis.

\subsection{Epidemiological Studies on Coffee/CGA}

A cross-sectional study in 137 patients with non-alcoholic fatty liver disease (NAFLD) and 108 controls showed that coffee consumption was inversely associated with obesity and insulin resistance [1,49]. The results of a Mendelian randomization study in 93,179 individuals demonstrated that coffee intake of up to four cups/day was associated with a lower risk of obesity with an odds ratios (ORs) of $0.82-0.86$, when compared with non-coffee drinkers [50].

Yonekura et al. [51] conducted a cross-sectional study in 232 Japanese women aged 40-65 years and found that daily coffee consumption was inversely associated with high BMI (adjusted OR: 0.14, CI: 0.14, 0.96) and body fat percentage (adjusted OR: 0.33, CI: 0.14, 0.82).

Recently, Koyama et al. [9] reported that coffee consumption is associated with significantly lower levels of visceral obesity (OR: 0.746, CI: 0.588, 0.947) and MetS (OR: 0.706, CI: $0.565,0.882$ ). These findings indicate the beneficial effects of coffee consumption toward obesity.

However, several studies failed to show such favorable effects. For example, an epidemiological study in 17,953 Korean adults aged 19-65 years failed to show that coffee consumption has health benefits; the OR for obesity of those who drank coffee $\geq 3$ times/day was 1.37 (CI: 1.15, 1.63) when compared with those who had coffee $<1$ time/week [52]. Similarly, an epidemiological study in 5995 women indicated that the ORs of high coffee consumption ( $\geq 3$ cups) were positively associated with obesity as measured by BMI (OR: 2.52 , CI: $1.91,3.34$ ) and abdominal obesity as measured by WC (OR: 2.11, CI: 1.59, 2.79) when compared with non-coffee drinkers [53]. Coffee with additives such as sugar was positively correlated with the prevalence of obesity.

\subsection{Clinical Studies on Coffee/CGA}

A systemic review of three RCTs, including 142 participants, observed a significant difference in body weight in a green coffee extract (GCE)-consuming group when compared with placebo (mean difference: $-2.47 \mathrm{~kg}, \mathrm{CI}:-4.23,-0.72$ ) [54].

A 12-week RCT in 30 overweight individuals reported that the average body weight loss in subjects who consumed CGA-enriched coffee was $5.4 \mathrm{~kg}$, while in the instant coffee groups, this was $1.7 \mathrm{~kg}$, suggesting a beneficial effect of CGA on body weight management [55].

Haidari et al. [56] conducted an 8-week RCT where 64 obese women were divided into the intervention group (receiving $400 \mathrm{mg} \mathrm{GCE}$, equivalent to $180 \mathrm{mg} \mathrm{CGA}, n=30$ ) or the control placebo group (receiving $400 \mathrm{mg}$ starch, $n=34$ ). As per the study results, significant reductions were noted in body weight, BMI, and fat mass indices, and waist-to-hip circumference ratios in both groups; however, the decrease was higher in the intervention group. In addition, serum TC, LDL, leptin, and plasma free FA levels were significantly decreased in the intervention group, after adjusting for energy and fiber intake.

In another RCT, 142 healthy overweight men and women were divided into two groups: the high CGA group (369 mg CGA/serving) and the control coffee group (35 mg CGA/serving). Coffee was consumed once daily for 12 weeks, with 4 -week pre- and post-observation periods. Body weight, BMI, VFA, total abdominal fat area (TFA), and WC were all significantly decreased in the high CGA group when compared with the control group. Changes in VFA $\left(-9.0 \pm 13.9 \mathrm{~cm}^{2}\right.$ in the CGA group vs. $-1.0 \pm 14.3 \mathrm{~cm}^{2}$ in the control) and TFA ( $-13.8 \pm 22.9 \mathrm{~cm}^{2}$ in the CGA group vs. $-2.0 \pm 16.2 \mathrm{~cm}^{2}$ in the control) from baseline to 12 weeks were found to be significantly higher in the high CGA group than in the control group [57]. 
An 8-week RCT was conducted in patients with NAFLD; patients were divided into an intervention group (400 mg green GCE containing $100 \mathrm{mg}$ CGA, $n=24$ ) or a placebo group $(n=24)$. The authors observed that GCE supplementation significantly reduced BMI (mean difference (MD): $-0.57, \mathrm{CI}:-0.84,-0.29)$ and increased serum high-density lipoprotein cholesterol (HDL-C) levels (MD: 7.06, CI: 0.25, 13.87) when compared with the placebo group. Serum TC decreased significantly in the GCE group (MD: $-13.33, \mathrm{CI}$ : $-26.04,-0.61)$ [58].

However, an RCT in 18 healthy male subjects who consumed $185 \mathrm{~mL}$ of a test beverage with or without CGAs (329 mg) per day for 4 weeks showed no effects on body weight, BMI, or body fat, although a significantly higher postprandial energy expenditure was observed in the CGA group when compared with the controls [59]. Thus, further studies are warranted to determine the effects of coffee and CGAs on obesity.

\subsection{Laboratory Studies and Mechanisms of CGA Action}

Several basic studies have generated evidence to support the beneficial effects of CGA on obesity. Cho et al. demonstrated that $0.02 \%(w / w)$ CGA supplementation can lower body weight and TG levels in plasma, liver, and heart in a HFD-induced mouse obesity model [60]. These authors also showed that CGA significantly inhibited liver-based FASN when compared with the high-fat group. In accordance with these findings, Huang et al. observed that $90 \mathrm{mg} / \mathrm{kg}$ CGA consumption suppressed HFD-induced increases in body weight, and downregulated FASN and ACC mRNA expression in rats [61].

In a rat study, CGA supplementation $(\sim 100 \mathrm{mg} / \mathrm{kg} /$ day) reduced inflammation and fat deposition in the liver, along with reduced plasma liver enzyme activities in diet-induced obese rats [62]. The inhibitory effects of fat-forming enzymes by CGA may be in part due to the regulation of upstream lipogenesis transcription factors. Wang et al. demonstrated that mice fed a HFD with CGA $(150 \mathrm{mg} / \mathrm{kg})$ had significantly lowered body weight in comparison to HFD-fed control mice. In epididymal adipose tissue, CGA significantly decreased FASN expression and expression of the upstream transcription factors, C/EBP, PPAR $\gamma$, and SREBP, but it increased PPAR $\alpha$ expression [63]. These findings agreed with the previous HFD-induced obesity studies in murine models [61,64], suggesting CGA improved metabolic homeostasis.

Additionally, CGA may reduce lipogenesis via AMPK activation, thereby inhibiting fat-forming enzymes [65]. In HepG2 cells, CGA (0.5-10 mM) induced AMPK activation in a dose- and time-dependent manner $(0.5-24 \mathrm{~h})$. Activated AMPK then inhibited fat synthesis by inhibiting fat-forming enzymes and lipogenesis transcription factors [33]. Hou et al. also demonstrated that CGA-treatment $(250 \mu \mathrm{M}$ and $1000 \mu \mathrm{M})$ for $24 \mathrm{~h}$ can induce ROS production in human colon cancer cells (HCT116 and HT26) [66]. Since AMPK was activated by ROS [67], CGA could regulate lipid metabolism via AMPK activation through ROS generation. Figure 2 outlines several CGA actions.

The ability of CGA to increase lipolysis may be associated with its anti-obesity effects. Flanagan et al. examined the long-term health benefits of CGA. They observed that CGA consumption for $192 \mathrm{~h}$ increased lipolysis, as measured by free FAs and glycerol [68]. In 3T3-L1 cells, $20 \mu \mathrm{M}$ CGA increased lipolysis by upregulating HSL expression [69,70]. These results suggested that CGA promoted lipid digestion by upregulating lipase expression.

Xu et al. [71] reported that mice fed a HFD supplemented with CGA and caffeine had significantly increased HSL and AMPK mRNA expression in the liver, when compared with the HFD group. CGA may also upregulate enzymes involved in FA $\beta$-oxidation, which in turn facilitates hepatic lipid degradation by activating PPAR $\alpha$ in the liver and adipose tissue [72]. These results indicated that CGA decreased obesity by enhancing lipolysis via AMPK activation [71] (Figure 2).

Ma et al. [64] reported that mice fed a HFD supplemented with CGA $(100 \mathrm{mg} / \mathrm{kg}$, twice a week) significantly suppressed the hepatic expression of CD36 when compared to the HFD group. Given that AMPK signaling plays a key role in CD36-induced lipid absorption [47], CGA may inhibit CD36 via AMPK activation, leading to reduced lipid 
uptake and transport. CGA may also affect lipid digestion by suppressing bile acid function, which is deemed critical for the digestion and absorption of lipids at the small intestine.

The microRNA-122 (miR-122) is liver specific and plays a critical role in liver homeostasis [73]; its inhibition is associated with the gene suppression of key roles in liver lipid metabolism, such as FASN [74]. Murase et al. demonstrated that CGA increased miR-122 levels in Hepa1-6 cells [75]. These results suggested that CGA may inhibit lipogenesis through post-transcriptional mechanisms.

\section{The Effects of Wine/RSV on Obesity}

\subsection{Observational Epidemiological Studies on the Anti-Obesity Effects of Wine/RSV}

Epidemiological studies have suggested that light to moderate consumption of alcohol may have protective effects against obesity [1]. A prospective cohort study which enrolled 15,920 normal-weight (BMI: $18.5 \mathrm{~kg} / \mathrm{m}^{2}$ to $<25 \mathrm{~kg} / \mathrm{m}^{2}$ ) postmenopausal women observed that the risk of becoming overweight and obese over a 7-year follow-up period was $35 \%$ and $88 \%$ lower, respectively, for women in the upper quintile of alcohol intake, relative to non-drinkers [76]. Of the alcoholic drinks, wine consumption showed the greatest inverse association for the risk of being overweight (hazard ratio (HR): $0.75, \mathrm{CI}, 0.68,0.84$ ), followed by liquor (HR: 0.85, CI: 0.78, 0.93) and beer (HR: 0.90, CI: 0.82, 1.00). Vidot et al. [77] reported that among wine drinkers, low and moderate drinkers had a lower OR for MetS when compared with non-drinkers (OR: 0.72, CI: 0.55, 0.96 and OR: 0.43, CI: 0.21, 0.87 , respectively). However, no significant associations were found for heavy wine (OR: 1.16$, CI: $0.43,3.16)$ and liquor drinkers.

Inan-Eroglu et al. [78] examined the associations between types of alcoholic drinks and adiposity in a large United Kingdom cohort ( $n=280,183,48.3 \%$ female). Study data indicated that when compared to non-wine drinkers, red wine, champagne, and fortified wine drinkers had lower BMIs (differences were as follows: $-0.75 \mathrm{~kg} / \mathrm{m}^{2}, \mathrm{CI}:-0.78$, $-0.72 \mathrm{~kg} / \mathrm{m}^{2} ;-0.48 \mathrm{~kg} / \mathrm{m}^{2}, \mathrm{CI}:-0.52,-0.45 \mathrm{~kg} / \mathrm{m}^{2}$; and $-0.24 \mathrm{~kg} / \mathrm{m}^{2}, \mathrm{CI}:-0.29,-0.18$ $\mathrm{kg} / \mathrm{m}^{2}$, respectively). Beer and spirits drinkers were determined to have higher BMIs when compared with non-beer and spirit drinkers (difference: $0.18 \mathrm{~kg} / \mathrm{m}^{2}$, CI: $0.14,0.22 \mathrm{~kg} / \mathrm{m}^{2}$, and difference: $0.64 \mathrm{~kg} / \mathrm{m}^{2}$, CI: $0.61,0.68 \mathrm{~kg} / \mathrm{m}^{2}$, respectively). A population-based study by Osella et al. showed that $>10 \mathrm{~g} /$ day of wine consumption was associated with being overweight [79].

A cross-sectional study in healthy volunteers (1481 women aged 35-60 years and 1210 men aged 45-60 years) showed a J-shaped relationship of waist-to-hip ratios and BMIs, in terms of wine consumption [80]. When compared with non-drinkers, men consuming $<100 \mathrm{~g} /$ day wine had a lower BMI, and lower waist-to-hip ratio was found in both men and women.

These findings suggest that low and moderate wine consumption may exert beneficial effects on obesity. However, a follow-up survey of 8103 subjects with a mean age of 35.4 years during $\geq 6$ years failed to show such beneficial effects; instead, results showed a non-significant association between wine consumption and MetS [81].

\subsection{Human Intervention Studies Investigating the Effects of Wine/RSV on Obesity}

Intervention studies have reported on the obesity-related effects of wine consumption. In an RCT in obese subjects who habitually consumed moderate alcohol levels, 40 of 49 eligible participants (BMI, $34.2 \pm 6.4 \mathrm{~kg} / \mathrm{m}^{2}$ ) completed the 3-month intervention study on a $1500 \mathrm{kcal}$ dietary regimen, one with $10 \%$ of energy from white wine and one with $10 \%$ of energy from grape juice [82]. These results showed that all subjects achieved significant body weight reduction; percent body fat, WC, blood pressure, blood glucose, insulin, TGs, and cholesterol were also reduced. In contrast, another RCT revealed that moderate wine consumption in overweight women did not improve insulin sensitivity and any other correlates of insulin sensitivity, i.e., body weight, blood lipids, and blood pressure [83].

In contrast to the studies focusing on wine consumption, the potential health benefits of RSV consumption have also been examined. Following a literature search, Wang 
et al. [4] summarized five RCTs published between 2009 and 2013, of which four reported favorable RSV effects. These included the downregulation of inflammatory markers, such as TNF- $\alpha$ and plasminogen activator inhibitor-1 (three studies), TGs (one study), LDL-C (one study), and nuclear factor- $\mathrm{KB}$ (NF- $\mathrm{kB}$, one study), and the upregulation of adiponectin (two studies), AMPK (one study), and SIRT1 (one study) [4].

In a comprehensive clinical study review, Wahab et al. [84] discussed the effects of RSV, and included 17 studies in patients with chronic diseases and 21 studies in healthy subjects. These authors reported the beneficial effects of RSV, including reduced body weight, BMI, fat weight, LDL-C levels, and adipocyte size, in addition to the downregulation of inflammatory cytokines such as TNF- $\alpha$. The authors also recorded elevated adiponectin levels and adipose tissue lipolysis.

In a recent review, Singh et al. [85] summarized a number of RSV clinical trials in patients with obesity, diabetes, cancers, MetS, Alzheimer's disease, cardiovascular disease, and inflammatory disease. These authors observed that RSVs exerted favorable effects in 13 of the 15 studies in patients with obesity, being overweight, and MetS.

In contrast, several studies published conflicting results in this area. For example, a study by Poulsen et al. [86] showed that the consumption of RSV (500 $\mathrm{mg}$ for 28 days) by 24 obese, but otherwise healthy males, resulted in non-significant changes in terms of obesity markers, total body mass, total body fat mass, and visceral and abdominal subcutaneous fat volumes. Meanwhile, Gualdoni et al. [87] reported that 10 healthy volunteers who consumed $5 \mathrm{~g}$ RSV showed a significant increase in TNF- $\alpha$ levels at $24 \mathrm{~h}$ after treatment when compared at baseline. Peripheral blood mononuclear cells or isolated monocytes showed that RSV potentiated TNF- $\alpha$ production stimulated by different Toll-like receptor agonists. Moreover, significant increases in NF- $\mathrm{kB}$ activities and p105 phosphorylation were indicative of alternative NF-kB pathway activation.

\subsection{Laboratory Studies and RSV Mechanisms}

Most cell-based and animal studies have described favorable effects for RSV, thereby supporting findings from epidemiological cohort and intervention studies. Baur et al. [88] demonstrated that RSV alleviated the negative impact of a high-calorie diet on overall health and lifespan in middle-aged mice. RSV increased insulin sensitivity, AMPK, and peroxisome proliferator-activated receptor- $\gamma$ coactivator- $1 \alpha$ (PGC- $1 \alpha)$ activity and reduced insulin-like growth factor-1 levels. Parametric analyses revealed that RSV gave the significant opposed effects of the high-calorie diet in 144 out of 153 altered pathways. Although this study showed that increased SIRT1 enzymatic activity by RSV without altering its gene expression, a different study showed that RSV restored its decreased mRNA levels induced by hemorrhagic shock in the rat kidney to the control levels [89].

Price et al. [90] reported different RSV dose-dependent activities toward AMPK and SIRT1 expression. Mice treated with a moderate RSV dose were able to activate AMPK, increasing mitochondrial biogenesis and function in skeletal muscle, whereas SIRT1 knockout mice displayed none of these effects. A mouse model over-expressing SIRT1 mimicked these effects, demonstrating SIRT1 was required for AMPK activation. In contrast, a high RSV dose activated AMPK in a SIRT1-independent manner, demonstrating RSV dosage was a critical factor [90]. These findings indicated that RSV exerted dose-dependent effects on AMPK and SIRT1 signaling pathways.

Wang et al. [4] reviewed 14 cell and 12 animal studies investigating the anti-obesity effects of RSV. Their data indicated: RSV increased adiponectin levels; reduced TG levels and lipid accumulation; upregulated AMPK, SIRT1, and SIRT3; downregulated FASN and PPAR $\gamma$; ameliorated drug-induced increases in TNF- $\alpha$ production; and activated NF- $\mathrm{kB}$. Animal study data indicated that the anti-obesity effects of RSV in animals were potentially mediated through stimulation of fat oxidation and metabolism, together with the suppression of adipogenic gene expression, such as PPAR, C/EBP $\alpha$, SREBP-1c, FASN, lipopolysaccharide (LPS), FA-binding protein (adipocyte Protein 2 (aP2)), and leptin. They also indicated that RSV not only downregulated obesity-induced chronic inflammation 
expression of TNF- $\alpha$, interferon (IFN)- $\gamma$, IFN- $\beta$, and IL- 6 , downstream signaling molecules, and oxidative stress, but it also upregulated anti-oxidant defense capacities, such as increased liver SOD, glutathione peroxidase, and catalase.

Based on clinical and preclinical data, Singh et al. [85] proposed the following RSV molecular targets: AMPK, GST, IL-1 $\beta$, matrix metalloproteinase (MMP), NF- $\mathrm{B} B$, nuclear factor erythroid like 2 (Nrf2), PGC- $1 \alpha$, SIRT1, and TNF- $\alpha$. Possible mechanisms, involving these targets, whereby RSV exerts anti-obesity effects are shown in Figure 2.

\section{The Effects of Curry/CRC on Obesity}

\subsection{Human Studies on Curry/CRC}

No comprehensive epidemiological studies have yet reported the effects of CRC on obesity. Future observational human studies may reveal its beneficial effects on obesity and other diseases, particularly in Asian populations which have high CRC consumption levels.

However, multiple clinical studies have reported on the health benefits of CRC consumption. In an RCT in MetS patients with BMIs between 25.0 and 29.9, 44 participants showed a $<2 \%$ weight loss after 30 days of diet, 22 patients were treated for a further 30 days with a CRC mixture $(800 \mathrm{mg} /$ dose/day of Curcuma longa extract containing $95 \%$ CRC), while the remaining 22 patients received vehicle $(400 \mathrm{mg} /$ dose/day of pure phosphatidylserine) [91]. These results indicated that CRC treatment increased weight loss from $1.88 \%$ to $4.91 \%$, enhanced the percentage reduction of body fat $(0.70 \%$ to $8.43 \%)$, waistline reduction $(2.36 \%$ to $4.14 \%)$, hip circumference reduction $(0.74 \%$ to $2.51 \%)$, and BMI reduction $(2.10 \%$ to $6.43 \%)$ [91].

Data from four clinical studies led Kunnumakkara et al. [92] to conclude that CRC was effective in reducing anxiety and depression symptoms associated with obesity. CRC modulated circulating IL-1 $\beta$, IL-4, and vascular endothelial growth factor (VEGF) levels to generate immunosuppressive effects and reduce oxidative stress in obese patients.

A systematic review of seven RCTs examining turmeric and CRC in patients at risk of cardiovascular disease suggested they had beneficial effects on serum TG and LDL-C levels, although no significant differences were found for serum HDL-C levels. When the analysis was restricted to more homogenous studies based on underlying different disease categories, a beneficial effect of turmeric and CRC on serum TC levels was noted in patients with MetS [93].

A meta-analysis of eight RCT reported a significant reduction (WMD: $-4.69 \mathrm{pg} / \mathrm{mL}$, CI: $-7.10,-2.28$ ) in circulating TNF- $\alpha$ levels upon CRC supplementation, suggesting a beneficial effect of CRC on inflammation [94].

A meta-analysis of 11 studies involving 876 subjects ( $53 \%$ women) found a significant effect of CRC on body weight (WMD: $-1.14 \mathrm{~kg}$, CI: $-2.16,-0.12$ ) and BMI (WMD: $\left.-0.48 \mathrm{~kg} / \mathrm{m}^{2}, \mathrm{CI}:-0.78,-0.17\right)$, respectively [95].

In an RCT by Saraf-Bank et al. [96], 60 overweight and obese adolescent girls were randomly assigned to either a placebo or CRC intervention group. Supplementation with $500 \mathrm{mg} /$ day CRC for 10 weeks was found to significantly lower IL-6 levels and oxidative stress markers, suggesting beneficial effects on inflammation and oxidative stress.

However, data from a 6-month RCT in elderly subjects who consumed CRC or placebo showed that CRC consumption (doses of either $1 \mathrm{~g}$ or $4 \mathrm{~g} /$ day) did not significantly affect TG, TC, LDL-C, or HDL-C levels over 1 or 6 months [97]. Data from another RCT, where 30 obese individuals were randomized to receive $1 \mathrm{~g}$ /day CRC or placebo, showed that CRC significantly reduced IL-1 $\beta$, IL-4, and VEGF serum levels, but no significant differences were observed for IL-2, IL-6, IL-8, IL-10, IFN- $\gamma$, epidermal growth factor, and monocyte chemoattractant protein-1 levels [98]. Thus, different studies show that the CRC effects on some biomarkers are variable.

\subsection{Laboratory Studies and CRC Mechanisms}

Several cell and animal studies have demonstrated the beneficial effects of CRC on obesity [4]. In a mouse model study, CRC administration for 28 weeks significantly 
attenuated the effects of HFD on body weight gain, glucose disposal, and insulin resistance. CRC also inhibited the expression of lipogenic genes, including NF- $\mathrm{B}$, SREBP-1c, and carbohydrate-responsive element-binding protein in the liver, and blocked the effects of HFD on inflammatory pathways in adipose tissue [99]. Similarly, dietary CRC ameliorated diabetes in HFD-induced obese and $o b / o b$ male C57BL/6J mice and further reduced body weight gain. CRC also decreased macrophage infiltration in white adipose tissue, adipose tissue adiponectin production, hepatic NF- $\mathrm{kB}$ activity, and hepatic inflammation [100].

In 3T3-L1 cells, Ahn et al. [101] showed that CRC decreased aP2 (a mature adipocyte marker) mRNA expression, increased c-Myc and cyclin D1 expression (well-known Wnt targets), and inhibited mitogen-activated protein kinase (MAPK) phosphorylation, which has been associated with 3T3-L1 differentiation into adipocytes. These findings suggest that the Wnt signaling pathway participated in CRC-induced suppression of adipogenesis in 3T3-L1 cells.

Wnt signaling activation represses adipogenic differentiation. The transcription factor 7-like 2 (Tcf7l2) gene encodes a key Wnt signaling pathway effector, and its human homologue, TCF7L2, may be a high-risk gene for diabetes. Tian et al. [102] showed that CRC attenuated miR-17-5p expression and stimulated Tcf7l2 expression in 3T3-L1 cells. Since miR-17-5p expression in mouse epididymal fat tissues increased in response to HFD, these finding suggested that miR-17-5p could be a central switch in adipogenic differentiation.

Ejaz et al. [103] demonstrated that in mice fed HFD, CRC reduced body weight gain, adiposity, and micro-vessel density in adipose tissue, which coincided with the reduced expression of VEGF and its receptor, VEGFR-2. CRC has also been noted to activate AMPK, reduce glycerol-3-phosphate acyl transferase-1, and increase carnitine palmitoyltransferase1 expression, leading to increased lipid oxidation and decreased fatty acid esterification.

Kunnumakkara et al. [92] characterized CRC molecular targets, including transcription factors, protein kinases, inflammatory mediators, apoptotic regulators, protein reductases and histone acetyl transferase, growth factors, receptors, and adhesion molecules. CRC may exert its multiple effects via epigenetic regulation, of which the major targets include Nrf2, $\beta$-catenin, NF- $\mathrm{B}$, p38 MAPK, cyclooxygenase-2, forkhead box O3, inducible nitric oxide synthase, ROS, cyclin D1, VEGF, glutathione, TNF- $\alpha$, and extracellular-regulated protein kinase.

Wang et al. [4] reviewed 11 cell-based, 16 animal, and 3 human studies investigating the anti-obesity effects induced by CRC and concluded CRC could down- or upregulate various transcription factors, enzymes, cytokines, and other signaling pathway components. More specifically, downregulated or inactivated molecules included C/EBP- $\alpha, \operatorname{PPAR} \gamma$, SREBP-1c, FASN, ACC, HSL, SREBP-1c, NF- - B, IL-6, and TNF- $\alpha$. Those upregulated or activated included AMPK, Nrf2, and SIRT1. How these molecules are involved in CRC anti-obesity effects is highlighted in Figure 2.

\section{Discussion}

This review summarized the favorable anti-obesity effects of consuming green tea, coffee, wine, and curry and their principal associated polyphenols. While considerable human observational and intervention studies have expounded this hypothesis, several studies have failed to show any beneficial effects. Such differences may have been due to confounding factors, e.g., differences in study design, quantifying consumption methods, beverage temperatures, cigarette smoking, alcohol consumption, and differences in genetic and environmental factors, such as race, sex, age, lifestyle, intestinal microbiota, and genetic polymorphisms [2,104,105]. Further complicating these issues is the fact that polyphenols have limited bioavailability as their absorption from the human digestive system is restricted; thus, they are predominantly metabolized in the gut and liver [106]. In the future, more comprehensive and definitive human studies should be performed to assess the bioavailability of polyphenols and prove the anti-obesity effects of consuming these foods. 
Most animal and cell-based studies supported the beneficial findings of human studies. These studies also proposed possible mechanisms underlying the anti-obesity actions of these polyphenols. Figure 2, which has been generated from previous data $[1,3,6,33,85,105,107-109]$ illustrates putative mechanism showing how EGCG, CGA, RSV, and CRC may exert their anti-obesity effects. These mechanisms are underpinned by the downregulation/inhibition of adipogenesis, lipogenesis, oxidative stress, and inflammation and the upregulation/stimulation of lipolysis and mitochondrial biogenesis.

Polyphenols are frequently documented with dual pro- and anti-oxidant roles (Table 1). This table shows that EGCG, CGA, RSV, and CRC upregulate AMPK by stimulating ROS generation, but downregulates NF- $\mathrm{kB}$ by scavenging ROS. A caveat to this table is that not all studies are necessarily related to obesity. Currently, it remains unclear what factor(s) direct these polyphenols to act as pro- or antioxidants; however, differences in cellular polyphenol and metal ion concentrations, cell types, and the co-existence of other antioxidants may be important factors. Thus, further studies will be required to clarify these issues. It should be noted that AMPK activation via TNF- $\alpha$ downregulation (Figure 2) is based on Steinberg et al. [107]; however, more evidence is required for this observation.

Epigenetic modifications, including post-translational changes caused by miRNA dysregulation (miRNAs are small single-stranded molecules comprising 20 to 25 nucleotides), are implicated in various cellular processes via gene expression regulation [110,111]. Several miRNAs are associated with obesity [112], e.g., miR-17-5p, miR-122, and miR-221.

Table 1. Studies showing EGCG, CGA, RSV, and CRC modulatory effects on ROS, AMPK, and NF-kB. Studies showing ROS and AMPK stimulation or upregulation are in red boxes, whereas studies showing ROS and NF- $\mathrm{B}$ suppression or downregulation are in blue boxes.

\begin{tabular}{|c|c|c|c|c|}
\hline Polyphenols & ROS & AMPK & ROS & NF- $\kappa B$ \\
\hline & $\begin{array}{l}\text { Stimulation/ } \\
\text { Upregulation }\end{array}$ & $\begin{array}{l}\text { Stimulation/ } \\
\text { Upregulation }\end{array}$ & $\begin{array}{c}\text { Suppression/ } \\
\text { Downregulation }\end{array}$ & $\begin{array}{c}\text { Suppression/ } \\
\text { Downregulation }\end{array}$ \\
\hline EGCG & $\begin{array}{c}\text { Tsai et al. [113] } \\
\text { Hsieh et al. [114] } \\
\text { Liu et al. [115] }\end{array}$ & $\begin{array}{l}\text { Tan et al. [116] } \\
\text { Bae et al. [117] } \\
\text { Ueda et al. [118] }\end{array}$ & $\begin{array}{l}\text { Wada et al. [119] } \\
\text { Qin et al. [120] } \\
\text { Yi et al. [121] }\end{array}$ & $\begin{array}{l}\text { Zhong et al. [122] } \\
\text { Wang et al. [123] } \\
\text { Reddy et al. [124] }\end{array}$ \\
\hline CGA & $\begin{array}{l}\text { Rakshit et al. [125] } \\
\text { Yang et al. [126] } \\
\text { Hou et al. [66] }\end{array}$ & $\begin{array}{l}\text { Zhou et al. [127] } \\
\text { Jang et al. [128] } \\
\text { Tsai et al. [129] }\end{array}$ & $\begin{array}{l}\text { Han et al. [130] } \\
\text { Gong et al. [131] } \\
\text { Kong et al. [132] }\end{array}$ & $\begin{array}{l}\text { Bao et al. [133] } \\
\text { Tian et al. [134] } \\
\text { Fu et al. [135] }\end{array}$ \\
\hline RSV & $\begin{array}{c}\text { Posadino et al. [136] } \\
\text { Chen et al. [137] } \\
\text { Li et al. [138] }\end{array}$ & $\begin{array}{c}\text { Vlavcheski et al. [139] } \\
\text { Guo et al. [140] } \\
\text { Wang et al. [141] }\end{array}$ & $\begin{array}{c}\text { Giordo et al. [142] } \\
\text { Ramdani et al. [143] } \\
\text { Zhang et al. [144] }\end{array}$ & $\begin{array}{c}\text { André et al. [145] } \\
\text { Subedi et al. [146] } \\
\text { Xian et al. [147] }\end{array}$ \\
\hline CRC & $\begin{array}{c}\text { Liang et al. [148] } \\
\text { Yu et al. [149] } \\
\text { Nakamae et al. [150] }\end{array}$ & $\begin{array}{c}\text { Soltani et al. [151] } \\
\text { Lu et al. [152] } \\
\text { Yu et al. [153] }\end{array}$ & $\begin{array}{l}\text { Sadeghi et al. [154] } \\
\text { Ran et al. [155] } \\
\text { Lin et al. [156] }\end{array}$ & $\begin{array}{c}\text { Li et al. [157] } \\
\text { Khan et al. [158] } \\
\text { Zhou et al. [159] }\end{array}$ \\
\hline
\end{tabular}

As described earlier, miR-122 and miR-17-5p were implicated as CRC and CGA targets, respectively [75,102]. The effects of EGCG, CGA, RSV, and CRC on miRNAs were then compared (Table 2), although it remains unclear how these miRNAs, other than miR-122 and miR-17-5p, are associated with anti-obesity effects mediated by these polyphenols. Table 2 indicates the polyphenols reviewed here downregulated miR-17 and miR-21, but differences exist among them in modulation of miR-33, miR-122, miR-155, and miR-221, suggesting different mechanisms may function in their anti-obesity effects.

Future studies will clarify whether these polyphenols have similar or different modulatory effects on these miRNAs. 
Table 2. MiRNA modulation by EGCG, CGA, RSV, and CRC polyphenols. Arrows in red boxes ( $\uparrow$ ) and blue boxes $(\downarrow)$ represent upregulation and downregulation, respectively.

\begin{tabular}{|c|c|c|c|c|c|}
\hline miRNA & Polyphenols & Modulation & Cell/Animal Model & Dose & References \\
\hline \multirow{4}{*}{ miR-17 } & EGCG & $\downarrow$ & Human umbilical vein endothelial cells & $50 \mathrm{mg} / \mathrm{mL}$ & [160] \\
\hline & CGA & $\downarrow$ & $\begin{array}{l}\text { Human hepatocellular carcinoma Huh7 cells and human } \\
\text { small cell lung cancer NCI-H446 cells }\end{array}$ & $25,50 \mathrm{mM}$ & [161] \\
\hline & RSV & $\downarrow$ & Human breast cancer cell lines (Bcap37, MDA-MB-231) & $6.25,25 \mathrm{mM}$ & [162] \\
\hline & CRC & $\downarrow$ & Mouse embryonic fibroblast 3T3-L1 cells & $2,10 \mathrm{mM}$ & [102] \\
\hline \multirow[t]{4}{*}{$\operatorname{miR}-21$} & EGCG & $\downarrow$ & Rat model of chronic renal injury & $200 \mathrm{mg} / \mathrm{kg}$ & {$[163]$} \\
\hline & CGA & $\downarrow$ & CCl4-induced liver fibrosis rat model & $15,30,60 \mathrm{mg} / \mathrm{kg}$ & {$[164]$} \\
\hline & RSV & $\downarrow$ & Human pancreatic stellate cells & $50 \mu \mathrm{M}$ & {$[165]$} \\
\hline & CRC & $\downarrow$ & Rat model of liver fibrosis & $100 \mathrm{mg} / \mathrm{kg}$ & [166] \\
\hline \multirow{4}{*}{$\operatorname{miR}-33$} & EGCG & $\downarrow$ & Human hepatoma HepG2 cells & $50 \mathrm{mM}$ & [74] \\
\hline & CGA & $\downarrow$ & Hypercholesterolemic rats model & $\begin{array}{c}75,150,300 \mathrm{mg} / \mathrm{kg} \text { of Lonicera caeruleaberry } \\
\text { extract containing CGA }\end{array}$ & [167] \\
\hline & RSV & $\uparrow$ & Human hepatoma HepG2 cells & $50 \mathrm{mM}$ & {$[74]$} \\
\hline & CRC & $\downarrow$ & Human THP-1 macrophages & $40 \mathrm{mM}$ & [168] \\
\hline \multirow{3}{*}{$\operatorname{miR}-122$} & CGA & $\downarrow$ & Hypercholesterolemic rats model & $\begin{array}{l}75,150,300 \mathrm{mg} / \mathrm{kg} \text { of L. caerulea berry } \\
\text { extract containing CGA }\end{array}$ & {$[167]$} \\
\hline & RSV & $\uparrow$ & Human hepatoma HepG2 cells & $50 \mathrm{mM}$ & [74] \\
\hline & CRC & $\uparrow$ & Bile duct ligation-induced fibrotic rats & $100 \mathrm{mg} / \mathrm{kg}$ & [169] \\
\hline \multirow[t]{4}{*}{ mir-155 } & EGCG & $\uparrow$ & Human colon cancer cell lines (HCT-116, DLD-1) & $50 \mathrm{mM}$ & {$[170]$} \\
\hline & CRC & $\downarrow$ & LPS-treated murine monocyte/macrophage RAW264.7 cells & $31.25,62.5 \mathrm{mM}$ & {$[171]$} \\
\hline & RSV & $\uparrow$ & Mouse embryonic fibroblast 3T3-L1 cells & $25 \mathrm{mM}$ & {$[172]$} \\
\hline & CRC & $\downarrow$ & LPS-induced mouse model of inflammation & $20 \mathrm{mg} / \mathrm{kg}$ & [173] \\
\hline \multirow[t]{3}{*}{$\operatorname{miR}-221$} & EGCG & $\uparrow$ & Rat pheochromocytoma PC12 cells & $50 \mathrm{mM}$ & {$[163]$} \\
\hline & RSV & $\uparrow$ & Human umbilical vein endothelial cells & $50 \mathrm{mM}$ & {$[174]$} \\
\hline & CRC & $\downarrow$ & Human hepatoma HepG2 cells xenograft mouse model & $100 \mathrm{mg} / \mathrm{kg}$ & [169] \\
\hline
\end{tabular}


Author Contributions: T.O.: corresponding author, literature search, text preparation of Section 1, drafting Figure 2, preparation of references. R.F.: literature search, text preparation of Section 4. Y.S.: literature search, text preparation of Section 2. S.G.: literature search, text preparation of Section 3, drawing Figure 1. M.I.: project design, outline of the manuscript, literature search, abstract preparation, introduction, and discussion. All authors have read and agreed to the published version of the manuscript.

Funding: This research received no external funding.

Institutional Review Board Statement: Not applicable.

Informed Consent Statement: Not applicable.

Data Availability Statement: Not applicable.

Conflicts of Interest: The authors declare no conflict of interest.

Sample Availability: Not applicable.

\section{Abbreviations}

\begin{tabular}{|c|c|}
\hline $\mathrm{ACC}$ & Acetyl-CoA carboxylase \\
\hline AMD & Adjusted mean difference \\
\hline AMPK & $5^{\prime}$-AMP-activated protein kinase \\
\hline $\mathrm{aP2}$ & Adipocyte Protein 2 \\
\hline BMI & Body mass index \\
\hline $\mathrm{C} / \mathrm{EBP}$ & CCAAT/enhancer-binding proteins \\
\hline CGA & Chlorogenic acid \\
\hline CD36 & Cluster of differentiation 36 \\
\hline $\mathrm{CI}$ & Confidence interval \\
\hline CRC & Curcumin \\
\hline EGCG & Epigallocatechin-3-O-gallate \\
\hline FAs & Fatty acids \\
\hline FAS/FASN & Fatty acid synthase \\
\hline GST & Glutathione S-transferase \\
\hline GCE & Green coffee extract \\
\hline GTE & Green tea extract \\
\hline HR & Hazard ratio \\
\hline HFD & High-fat diet \\
\hline HSL & Hormone-sensitive lipase \\
\hline $\mathrm{IC}_{50}$ & Half-maximal inhibitory concentration \\
\hline IFN & Interferon \\
\hline IL & Interleukin \\
\hline LPS & Lipopolysaccharide \\
\hline LXR & Liver $\mathrm{X}$ receptor \\
\hline LDL & Low-density lipoprotein \\
\hline MMP & Matrix metalloproteinase \\
\hline MD & Mean difference \\
\hline MetS & Metabolic syndrome \\
\hline MAPK & Mitogen-activated protein kinase \\
\hline MS & Multiple sclerosis \\
\hline NAFLD & Non-alcoholic fatty liver disease \\
\hline Nrf2 & Nuclear factor erythroid 2-like 2 \\
\hline NF- $k B$ & Nuclear factor- $\kappa \mathrm{B}$ \\
\hline ORs & Odds ratios \\
\hline PGC-1 $\alpha$ & Peroxisome proliferator-activated receptor- $\gamma$ coactivator- $1 \alpha$ \\
\hline PPAR & Peroxisome proliferation-activated receptor \\
\hline $\mathrm{RCT}$ & Randomized controlled trial \\
\hline ROS & Reactive oxygen species \\
\hline RSV & Resveratrol \\
\hline
\end{tabular}




$\begin{array}{ll}\text { SIRT } & \text { Sirtuin } \\ \text { SCD } & \text { Stearoyl-CoA desaturase } \\ \text { SOD } & \text { Superoxide dismutase } \\ \text { SREBP } & \text { Sterol regulatory element-binding proteins } \\ \text { TFA } & \text { Total abdominal fat area } \\ \text { TC } & \text { Total cholesterol } \\ \text { Tcf712 } & \text { Transcription factor 7-like } 2 \\ \text { TGs } & \text { Triglycerides } \\ \text { TNF } & \text { Tumor necrosis factor } \\ \text { VEGF } & \text { Vascular endothelial growth factor } \\ \text { VFA } & \text { Visceral fat area } \\ \text { WC } & \text { Waist circumference } \\ \text { WMD } & \text { Weighted mean difference }\end{array}$

\section{References}

1. Tanabe, H.; Pervin, M.; Goto, S.; Isemura, M.; Nakamura, Y. Beneficial Effects of Plant Polyphenols on Obesity. Obes. Control Ther. 2017, 4, 1-16. [CrossRef]

2. Hayakawa, S.; Oishi, Y.; Tanabe, H.; Isemura, M.; Suzuki, Y. Tea, Coffee and Health Benefits. In Bioactive Molecules in Food; Mérillon, J.-M., Ramawat, K.G., Eds.; Springer International Publishing: Cham, Switzerland, 2018; pp. 1-58. ISBN 978-3-319-78029-0.

3. Hayakawa, S.; Ohishi, T.; Miyoshi, N.; Oishi, Y.; Nakamura, Y.; Isemura, M. Anti-Cancer Effects of Green Tea Epigallocatchin-3Gallate and Coffee Chlorogenic Acid. Molecules 2020, 25, 4553. [CrossRef] [PubMed]

4. Wang, S.; Moustaid-Moussa, N.; Chen, L.; Mo, H.; Shastri, A.; Su, R.; Bapat, P.; Kwun, I.; Shen, C.L. Novel insights of dietary polyphenols and obesity. J. Nutr. Biochem. 2014, 25, 1-18. [CrossRef] [PubMed]

5. Pastor, R.F.; Restani, P.; Di Lorenzo, C.; Orgiu, F.; Teissedre, P.L.; Stockley, C.; Ruf, J.C.; Quini, C.I.; Garcia Tejedor, N.; Gargantini, R.; et al. Resveratrol, human health and winemaking perspectives. Crit. Rev. Food Sci. Nutr. 2019, 59, 1237-1255. [CrossRef] [PubMed]

6. Suzuki, T.; Pervin, M.; Goto, S.; Isemura, M.; Nakamura, Y. Beneficial Effects of Tea and the Green Tea Catechin Epigallocatechin3-gallate on Obesity. Molecules 2016, 21, 1305. [CrossRef] [PubMed]

7. Saeki, K.; Hayakawa, S.; Nakano, S.; Ito, S.; Oishi, Y.; Suzuki, Y.; Isemura, M. In Vitro and In Silico Studies of the Molecular Interactions of Epigallocatechin-3-O-gallate (EGCG) with Proteins That Explain the Health Benefits of Green Tea. Molecules 2018, 23, 1295. [CrossRef] [PubMed]

8. Wu, C.H.; Lu, F.H.; Chang, C.S.; Chang, T.C.; Wang, R.H.; Chang, C.J. Relationship among habitual tea consumption, percent body fat, and body fat distribution. Obes. Res. 2003, 11, 1088-1095. [CrossRef] [PubMed]

9. Koyama, T.; Maekawa, M.; Ozaki, E.; Kuriyama, N.; Uehara, R. Daily Consumption of Coffee and Eating Bread at Breakfast Time Is Associated with Lower Visceral Adipose Tissue and with Lower Prevalence of Both Visceral Obesity and Metabolic Syndrome in Japanese Populations: A Cross-Sectional Study. Nutrients 2020, 12, 3090. [CrossRef]

10. Kao, Y.H.; Chang, H.H.; Lee, M.J.; Chen, C.L. Tea, obesity, and diabetes. Mol. Nutr. Food Res. 2006, 50, 188-210. [CrossRef]

11. Thielecke, F.; Boschmann, M. The potential role of green tea catechins in the prevention of the metabolic syndrome-a review. Phytochemistry 2009, 70, 11-24. [CrossRef]

12. Basu, A.; Sanchez, K.; Leyva, M.J.; Wu, M.; Betts, N.M.; Aston, C.E.; Lyons, T.J. Green tea supplementation affects body weight, lipids, and lipid peroxidation in obese subjects with metabolic syndrome. J. Am. Coll. Nutr. 2010, 29, 31-40. [CrossRef] [PubMed]

13. Nagao, T.; Hase, T.; Tokimitsu, I. A green tea extract high in catechins reduces body fat and cardiovascular risks in humans. Obesity 2007, 15, 1473-1483. [CrossRef] [PubMed]

14. Huang, J.; Wang, Y.; Xie, Z.; Zhou, Y.; Zhang, Y.; Wan, X. The anti-obesity effects of green tea in human intervention and basic molecular studies. Eur. J. Clin. Nutr. 2014, 68, 1075-1087. [CrossRef] [PubMed]

15. Chen, I.J.; Liu, C.Y.; Chiu, J.P.; Hsu, C.H. Therapeutic effect of high-dose green tea extract on weight reduction: A randomized, double-blind, placebo-controlled clinical trial. Clin. Nutr. 2016, 35, 592-599. [CrossRef] [PubMed]

16. Huang, L.H.; Liu, C.Y.; Wang, L.Y.; Huang, C.J.; Hsu, C.H. Effects of green tea extract on overweight and obese women with high levels of low density-lipoprotein-cholesterol (LDL-C): A randomised, double-blind, and cross-over placebo-controlled clinical trial. BMC Complement. Altern. Med. 2018, 18, 294. [CrossRef] [PubMed]

17. Basil, J.S.; Santoro, S.L.; Martin, L.J.; Healy, K.W.; Chini, B.A.; Saal, H.M. Retrospective Study of Obesity in Children with Down Syndrome. J. Pediatr. 2016, 173, 143-148. [CrossRef] [PubMed]

18. Xicota, L.; Rodriguez, J.; Langohr, K.; Fito, M.; Dierssen, M.; de la Torre, R. Effect of epigallocatechin gallate on the body composition and lipid profile of down syndrome individuals: Implications for clinical management. Clin. Nutr. 2020, 39, 1292-1300. [CrossRef] [PubMed]

19. Lin, Y.; Shi, D.; Su, B.; Wei, J.; Gaman, M.A.; Sedanur Macit, M.; Borges do Nascimento, I.J.; Guimaraes, N.S. The effect of green tea supplementation on obesity: A systematic review and dose-response meta-analysis of randomized controlled trials. Phytother. Res. 2020, 34, 2459-2470. [CrossRef] 
20. Igarashi, Y.; Obara, T.; Ishikuro, M.; Matsubara, H.; Shigihara, M.; Metoki, H.; Kikuya, M.; Sameshima, Y.; Tachibana, H.; Maeda-Yamamoto, M.; et al. Randomized controlled trial of the effects of consumption of Yabukita or Benifuuki encapsulated tea-powder on low-density lipoprotein cholesterol level and body weight. Food Nutr. Res. 2017, 61, 1334484. [CrossRef]

21. Dostal, A.M.; Samavat, H.; Espejo, L.; Arikawa, A.Y.; Stendell-Hollis, N.R.; Kurzer, M.S. Green Tea Extract and Catechol-OMethyltransferase Genotype Modify Fasting Serum Insulin and Plasma Adiponectin Concentrations in a Randomized Controlled Trial of Overweight and Obese Postmenopausal Women. J. Nutr. 2016, 146, 38-45. [CrossRef]

22. Pemble, C.W.; Johnson, L.C.; Kridel, S.J.; Lowther, W.T. Crystal structure of the thioesterase domain of human fatty acid synthase inhibited by Orlistat. Nat. Struct. Mol. Biol. 2007, 14, 704-709. [CrossRef] [PubMed]

23. Cioccoloni, G.; Aquino, A.; Notarnicola, M.; Caruso, M.G.; Bonmassar, E.; Zonfrillo, M.; Caporali, S.; Faraoni, I.; Villiva, C.; Fuggetta, M.P.; et al. Fatty acid synthase inhibitor orlistat impairs cell growth and down-regulates PD-L1 expression of a human T-cell leukemia line. J. Chemother. 2020, 32, 30-40. [CrossRef] [PubMed]

24. Tian, W.X. Inhibition of fatty acid synthase by polyphenols. Curr. Med. Chem. 2006, 13, 967-977. [CrossRef] [PubMed]

25. Zhang, R.; Xiao, W.; Wang, X.; Wu, X.; Tian, W. Novel inhibitors of fatty-acid synthase from green tea (Camellia sinensis Xihu Longjing) with high activity and a new reacting site. Biotechnol. Appl. Biochem. 2006, 43, 1-7. [PubMed]

26. Wolfram, S.; Raederstorff, D.; Wang, Y.; Teixeira, S.R.; Elste, V.; Weber, P. TEAVIGO (epigallocatechin gallate) supplementation prevents obesity in rodents by reducing adipose tissue mass. Ann. Nutr. Metab. 2005, 49, 54-63. [CrossRef]

27. Harada, N.; Oda, Z.; Hara, Y.; Fujinami, K.; Okawa, M.; Ohbuchi, K.; Yonemoto, M.; Ikeda, Y.; Ohwaki, K.; Aragane, K.; et al. Hepatic de novo lipogenesis is present in liver-specific ACC1-deficient mice. Mol. Cell Biol. 2007, 27, 1881-1888. [CrossRef]

28. Abdel-Magid, A.F. Treatment of Obesity and Related Disorders with Acetyl-CoA Carboxylase Inhibitors. ACS Med. Chem. Lett. 2013, 4, 16-17. [CrossRef]

29. Umek, R.M.; Friedman, A.D.; McKnight, S.L. CCAAT-enhancer binding protein: A component of a differentiation switch. Science 1991, 251, 288-292. [CrossRef]

30. Tontonoz, P.; Hu, E.; Spiegelman, B.M. Stimulation of adipogenesis in fibroblasts by PPAR gamma 2, a lipid-activated transcription factor. Cell 1994, 79, 1147-1156. [CrossRef]

31. Swinnen, J.V.; Ulrix, W.; Heyns, W.; Verhoeven, G. Coordinate regulation of lipogenic gene expression by androgens: Evidence for a cascade mechanism involving sterol regulatory element binding proteins. Proc. Natl. Acad. Sci. USA 1997, 94, 12975-12980. [CrossRef]

32. Lee, M.S.; Kim, C.T.; Kim, Y. Green tea (-)-epigallocatechin-3-gallate reduces body weight with regulation of multiple genes expression in adipose tissue of diet-induced obese mice. Ann. Nutr. Metab. 2009, 54, 151-157. [CrossRef] [PubMed]

33. Yang, C.S.; Zhang, J.; Zhang, L.; Huang, J.; Wang, Y. Mechanisms of body weight reduction and metabolic syndrome alleviation by tea. Mol. Nutr. Food Res. 2016, 60, 160-174. [CrossRef] [PubMed]

34. Collins, Q.F.; Liu, H.Y.; Pi, J.; Liu, Z.; Quon, M.J.; Cao, W. Epigallocatechin-3-gallate (EGCG), a green tea polyphenol, suppresses hepatic gluconeogenesis through 5'-AMP-activated protein kinase. J. Biol. Chem. 2007, 282, 30143-30149. [CrossRef] [PubMed]

35. Kim, H.S.; Quon, M.J.; Kim, J.A. New insights into the mechanisms of polyphenols beyond antioxidant properties; lessons from the green tea polyphenol, epigallocatechin 3-gallate. Redox Biol. 2014, 2, 187-195. [CrossRef] [PubMed]

36. Lee, M.S.; Kim, C.T.; Kim, I.H.; Kim, Y. Inhibitory effects of green tea catechin on the lipid accumulation in 3T3-L1 adipocytes. Phytother. Res. 2009, 23, 1088-1091. [CrossRef]

37. Rocha, A.; Bolin, A.P.; Cardoso, C.A.; Otton, R. Green tea extract activates AMPK and ameliorates white adipose tissue metabolic dysfunction induced by obesity. Eur. J. Nutr. 2016, 55, 2231-2244. [CrossRef]

38. Li, F.; Gao, C.; Yan, P.; Zhang, M.; Wang, Y.; Hu, Y.; Wu, X.; Wang, X.; Sheng, J. EGCG Reduces Obesity and White Adipose Tissue Gain Partly Through AMPK Activation in Mice. Front. Pharm. 2018, 9, 1366. [CrossRef]

39. Yuan, H.; Li, Y.; Ling, F.; Guan, Y.; Zhang, D.; Zhu, Q.; Liu, J.; Wu, Y.; Niu, Y. The phytochemical epigallocatechin gallate prolongs the lifespan by improving lipid metabolism, reducing inflammation and oxidative stress in high-fat diet-fed obese rats. Aging Cell 2020, e13199. [CrossRef]

40. Leone, T.C.; Weinheimer, C.J.; Kelly, D.P. A critical role for the peroxisome proliferator-activated receptor alpha (PPARalpha) in the cellular fasting response: The PPARalpha-null mouse as a model of fatty acid oxidation disorders. Proc. Natl. Acad. Sci. USA 1999, 96, 7473-7478. [CrossRef]

41. Cotter, D.G.; Ercal, B.; d'Avignon, D.A.; Dietzen, D.J.; Crawford, P.A. Impairments of hepatic gluconeogenesis and ketogenesis in PPARalpha-deficient neonatal mice. Am. J. Physiol. Endocrinol. Metab. 2014, 307, E176-E185. [CrossRef]

42. Sae-Tan, S.; Grove, K.A.; Kennett, M.J.; Lambert, J.D. (-)-Epigallocatechin-3-gallate increases the expression of genes related to fat oxidation in the skeletal muscle of high fat-fed mice. Food Funct. 2011, 2, 111-116. [CrossRef] [PubMed]

43. Murase, T.; Nagasawa, A.; Suzuki, J.; Hase, T.; Tokimitsu, I. Beneficial effects of tea catechins on diet-induced obesity: Stimulation of lipid catabolism in the liver. Int. J. Obes. Relat. Metab. Disord. 2002, 26, 1459-1464. [CrossRef] [PubMed]

44. Marechal, L.; Laviolette, M.; Rodrigue-Way, A.; Sow, B.; Brochu, M.; Caron, V.; Tremblay, A. The CD36-PPARgamma Pathway in Metabolic Disorders. Int. J. Mol. Sci. 2018, 19, 1529. [CrossRef] [PubMed]

45. Lu, J.; Fang, B.; Huang, Y.; Tao, S.; Sun, B.; Guan, S.; Jin, Y. Epigallocatechin-3-gallate protects against 1,3-dichloro-2-propanolinduced lipid accumulation in C57BL/6J mice. Life Sci. 2018, 209, 324-331. [CrossRef] [PubMed]

46. Calvo, D.; Gomez-Coronado, D.; Suarez, Y.; Lasuncion, M.A.; Vega, M.A. Human CD36 is a high affinity receptor for the native lipoproteins HDL, LDL, and VLDL. J. Lipid Res. 1998, 39, 777-788. [PubMed] 
47. Chabowski, A.; Coort, S.L.; Calles-Escandon, J.; Tandon, N.N.; Glatz, J.F.; Luiken, J.J.; Bonen, A. The subcellular compartmentation of fatty acid transporters is regulated differently by insulin and by AICAR. Febs. Lett. 2005, 579, 2428-2432. [CrossRef]

48. Santos, R.M.; Lima, D.R. Coffee consumption, obesity and type 2 diabetes: A mini-review. Eur. J. Nutr. 2016, 55, 1345-1358. [CrossRef]

49. Catalano, D.; Martines, G.F.; Tonzuso, A.; Pirri, C.; Trovato, F.M.; Trovato, G.M. Protective role of coffee in non-alcoholic fatty liver disease (NAFLD). Dig. Dis. Sci. 2010, 55, 3200-3206. [CrossRef]

50. Nordestgaard, A.T.; Thomsen, M.; Nordestgaard, B.G. Coffee intake and risk of obesity, metabolic syndrome and type 2 diabetes: A Mendelian randomization study. Int. J. Epidemiol. 2015, 44, 551-565. [CrossRef]

51. Yonekura, Y.; Terauchi, M.; Hirose, A.; Odai, T.; Kato, K.; Miyasaka, N. Daily Coffee and Green Tea Consumption Is Inversely Associated with Body Mass Index, Body Fat Percentage, and Cardio-Ankle Vascular Index in Middle-Aged Japanese Women: A Cross-Sectional Study. Nutrients 2020, 12, 1370. [CrossRef]

52. Kim, H.J.; Cho, S.; Jacobs, D.R., Jr.; Park, K. Instant coffee consumption may be associated with higher risk of metabolic syndrome in Korean adults. Diabetes Res. Clin. Pract. 2014, 106, 145-153. [CrossRef] [PubMed]

53. Lee, J.; Kim, H.Y.; Kim, J. Coffee Consumption and the Risk of Obesity in Korean Women. Nutrients 2017, 9, 1340. [CrossRef] [PubMed]

54. Onakpoya, I.; Terry, R.; Ernst, E. The use of green coffee extract as a weight loss supplement: A systematic review and metaanalysis of randomised clinical trials. Gastroenterol. Res. Pract. 2011, 2011. [CrossRef] [PubMed]

55. Thom, E. The effect of chlorogenic acid enriched coffee on glucose absorption in healthy volunteers and its effect on body mass when used long-term in overweight and obese people. J. Int. Med. Res. 2007, 35, 900-908. [CrossRef] [PubMed]

56. Haidari, F.; Samadi, M.; Mohammadshahi, M.; Jalali, M.T.; Engali, K.A. Energy restriction combined with green coffee bean extract affects serum adipocytokines and the body composition in obese women. Asia Pac. J. Clin. Nutr. 2017, 26, 1048-1054. [PubMed]

57. Watanabe, T.; Kobayashi, S.; Yamaguchi, T.; Hibi, M.; Fukuhara, I.; Osaki, N. Coffee Abundant in Chlorogenic Acids Reduces Abdominal Fat in Overweight Adults: A Randomized, Double-Blind, Controlled Trial. Nutrients 2019, 11, 1617. [CrossRef] [PubMed]

58. Hosseinabadi, S.; Rafraf, M.; Asghari, S.; Asghari-Jafarabadi, M.; Vojouhi, S. Effect of green coffee extract supplementation on serum adiponectin concentration and lipid profile in patients with non-alcoholic fatty liver disease: A randomized, controlled trial. Complementary Med. 2020, 49, 102290. [CrossRef]

59. Soga, S.; Ota, N.; Shimotoyodome, A. Stimulation of postprandial fat utilization in healthy humans by daily consumption of chlorogenic acids. Biosci. Biotechnol. Biochem. 2013, 77, 1633-1636. [CrossRef]

60. Cho, A.S.; Jeon, S.M.; Kim, M.J.; Yeo, J.; Seo, K.I.; Choi, M.S.; Lee, M.K. Chlorogenic acid exhibits anti-obesity property and improves lipid metabolism in high-fat diet-induced-obese mice. Food Chem. Toxicol. 2010, 48, 937-943. [CrossRef]

61. Huang, K.; Liang, X.C.; Zhong, Y.L.; He, W.Y.; Wang, Z. 5-Caffeoylquinic acid decreases diet-induced obesity in rats by modulating PPARalpha and LXRalpha transcription. J. Sci. Food Agric. 2015, 95, 1903-1910. [CrossRef]

62. Friedman, T.C.; Davies, T.F.; Wilk, S. Evidence for regulation of a thyrotropin-releasing hormone degradation pathway in GH3 cells. Endocrinology 1986, 118, 562-566. [CrossRef] [PubMed]

63. Wang, Z.; Lam, K.L.; Hu, J.; Ge, S.; Zhou, A.; Zheng, B.; Zeng, S.; Lin, S. Chlorogenic acid alleviates obesity and modulates gut microbiota in high-fat-fed mice. Food Sci. Nutr. 2019, 7, 579-588. [CrossRef] [PubMed]

64. Ma, Y.; Gao, M.; Liu, D. Chlorogenic acid improves high fat diet-induced hepatic steatosis and insulin resistance in mice. Pharm. Res. 2015, 32, 1200-1209. [CrossRef] [PubMed]

65. Ong, K.W.; Hsu, A.; Tan, B.K. Anti-diabetic and anti-lipidemic effects of chlorogenic acid are mediated by ampk activation. Biochem. Pharm. 2013, 85, 1341-1351. [CrossRef] [PubMed]

66. Hou, N.; Liu, N.; Han, J.; Yan, Y.; Li, J. Chlorogenic acid induces reactive oxygen species generation and inhibits the viability of human colon cancer cells. Anticancer Drugs 2017, 28, 59-65. [CrossRef] [PubMed]

67. Choi, S.L.; Kim, S.J.; Lee, K.T.; Kim, J.; Mu, J.; Birnbaum, M.J.; Soo Kim, S.; Ha, J. The regulation of AMP-activated protein kinase by $\mathrm{H}(2) \mathrm{O}(2)$. Biochem. Biophys Res. Commun. 2001, 287, 92-97. [CrossRef] [PubMed]

68. Flanagan, J.; Bily, A.; Rolland, Y.; Roller, M. Lipolytic activity of Svetol(R), a decaffeinated green coffee bean extract. Phytother. Res. 2014, 28, 946-948. [CrossRef]

69. Peng, S.G.; Pang, Y.L.; Zhu, Q.; Kang, J.H.; Liu, M.X.; Wang, Z. Chlorogenic Acid Functions as a Novel Agonist of PPARgamma2 during the Differentiation of Mouse 3T3-L1 Preadipocytes. BioMed Res. Int. 2018, 2018, 8594767. [CrossRef]

70. Liu, G.; Huang, Y.; Reis, F.S.; Song, D.; Ni, H. Impact of Nutritional and Environmental Factors on Inflammation, Oxidative Stress, and the Microbiome 2019. BioMed Res. Int. 2019, 2019, 5716241. [CrossRef]

71. Xu, M.; Yang, L.; Zhu, Y.; Liao, M.; Chu, L.; Li, X.; Lin, L.; Zheng, G. Collaborative effects of chlorogenic acid and caffeine on lipid metabolism via the AMPKalpha-LXRalpha/SREBP-1c pathway in high-fat diet-induced obese mice. Food Funct. 2019, 10, 7489-7497. [CrossRef]

72. Herranz-Lopez, M.; Olivares-Vicente, M.; Rodriguez Gallego, E.; Encinar, J.A.; Perez-Sanchez, A.; Ruiz-Torres, V.; Joven, J.; Roche, E.; Micol, V. Quercetin metabolites from Hibiscus sabdariffa contribute to alleviate glucolipotoxicity-induced metabolic stress in vitro. Food Chem. Toxicol. 2020, 144, 111606. [CrossRef] [PubMed] 
73. Hsu, S.H.; Wang, B.; Kota, J.; Yu, J.; Costinean, S.; Kutay, H.; Yu, L.; Bai, S.; La Perle, K.; Chivukula, R.R.; et al. Essential metabolic, anti-inflammatory, and anti-tumorigenic functions of miR-122 in liver. J. Clin. Investig. 2012, 122, 2871-2883. [CrossRef] [PubMed]

74. Baselga-Escudero, L.; Blade, C.; Ribas-Latre, A.; Casanova, E.; Suarez, M.; Torres, J.L.; Salvado, M.J.; Arola, L.; Arola-Arnal, A. Resveratrol and EGCG bind directly and distinctively to miR-33a and miR-122 and modulate divergently their levels in hepatic cells. Nucleic Acids Res. 2014, 42, 882-892. [CrossRef] [PubMed]

75. Murase, T.; Misawa, K.; Minegishi, Y.; Aoki, M.; Ominami, H.; Suzuki, Y.; Shibuya, Y.; Hase, T. Coffee polyphenols suppress diet-induced body fat accumulation by downregulating SREBP-1c and related molecules in C57BL/6J mice. Am. J. Physiol. Endocrinol. Metab. 2011, 300, E122-E133. [CrossRef] [PubMed]

76. Thomson, C.A.; Wertheim, B.C.; Hingle, M.; Wang, L.; Neuhouser, M.L.; Gong, Z.; Garcia, L.; Stefanick, M.L.; Manson, J.E. Alcohol consumption and body weight change in postmenopausal women: Results from the Women's Health Initiative. Int. J. Obes. 2012, 36, 1158-1164. [CrossRef]

77. Vidot, D.C.; Stoutenberg, M.; Gellman, M.; Arheart, K.L.; Teng, Y.; Daviglus, M.L.; Gonzalez, H.M.; Talavera, G.; Isasi, C.R.; Heiss, G.; et al. Alcohol Consumption and Metabolic Syndrome Among Hispanics/Latinos: The Hispanic Community Health Study/Study of Latinos. Metab. Syndr. Relat. Disord. 2016, 14, 354-362. [CrossRef]

78. Inan-Eroglu, E.; Powell, L.; Hamer, M.; O’Donovan, G.; Duncan, M.J.; Stamatakis, E. Is There a Link between Different Types of Alcoholic Drinks and Obesity? An Analysis of 280,183 UK Biobank Participants. Int. J. Env. Res. Public Health 2020, $17,5174$. [CrossRef]

79. Osella, A.R.; Diaz Mdel, P.; Cozzolongo, R.; Bonfiglio, C.; Franco, I.; Abrescia, D.I.; Bianco, A.; Giampiero, E.S.; Petruzzi, J.; Elsa, L.; et al. Overweight and Obesity in Southern Italy: Their association with social and life-style characteristics and their effect on levels of biologic markers. Rev. Fac. Cienc. Med. Cordoba 2014, 71, 113-124.

80. Lukasiewicz, E.; Mennen, L.I.; Bertrais, S.; Arnault, N.; Preziosi, P.; Galan, P.; Hercberg, S. Alcohol intake in relation to body mass index and waist-to-hip ratio: The importance of type of alcoholic beverage. Public Health Nutr. 2005, 8, 315-320. [CrossRef]

81. Barrio-Lopez, M.T.; Bes-Rastrollo, M.; Sayon-Orea, C.; Garcia-Lopez, M.; Fernandez-Montero, A.; Gea, A.; Martinez-Gonzalez, M.A. Different types of alcoholic beverages and incidence of metabolic syndrome and its components in a Mediterranean cohort. Clin. Nutr. 2013, 32, 797-804. [CrossRef]

82. Flechtner-Mors, M.; Biesalski, H.K.; Jenkinson, C.P.; Adler, G.; Ditschuneit, H.H. Effects of moderate consumption of white wine on weight loss in overweight and obese subjects. Int. J. Obes. Relat. Metab. Disord. 2004, 28, 1420-1426. [CrossRef] [PubMed]

83. Cordain, L.; Melby, C.L.; Hamamoto, A.E.; O’Neill, D.S.; Cornier, M.A.; Barakat, H.A.; Israel, R.G.; Hill, J.O. Influence of moderate chronic wine consumption on insulin sensitivity and other correlates of syndrome X in moderately obese women. Metabolism 2000, 49, 1473-1478. [CrossRef] [PubMed]

84. Wahab, A.; Gao, K.; Jia, C.; Zhang, F.; Tian, G.; Murtaza, G.; Chen, J. Significance of Resveratrol in Clinical Management of Chronic Diseases. Molecules 2017, 22, 1329. [CrossRef] [PubMed]

85. Singh, A.P.; Singh, R.; Verma, S.S.; Rai, V.; Kaschula, C.H.; Maiti, P.; Gupta, S.C. Health benefits of resveratrol: Evidence from clinical studies. Med. Res. Rev. 2019, 39, 1851-1891. [CrossRef]

86. Poulsen, M.M.; Vestergaard, P.F.; Clasen, B.F.; Radko, Y.; Christensen, L.P.; Stodkilde-Jorgensen, H.; Moller, N.; Jessen, N.; Pedersen, S.B.; Jorgensen, J.O. High-dose resveratrol supplementation in obese men: An investigator-initiated, randomized, placebo-controlled clinical trial of substrate metabolism, insulin sensitivity, and body composition. Diabetes 2013, 62, $1186-1195$. [CrossRef]

87. Gualdoni, G.A.; Kovarik, J.J.; Hofer, J.; Dose, F.; Pignitter, M.; Doberer, D.; Steinberger, P.; Somoza, V.; Wolzt, M.; Zlabinger, G.J. Resveratrol enhances TNF-alpha production in human monocytes upon bacterial stimulation. Biochim. Biophys Acta 2014, 1840, 95-105. [CrossRef]

88. Baur, J.A.; Pearson, K.J.; Price, N.L.; Jamieson, H.A.; Lerin, C.; Kalra, A.; Prabhu, V.V.; Allard, J.S.; Lopez-Lluch, G.; Lewis, K.; et al. Resveratrol improves health and survival of mice on a high-calorie diet. Nature 2006, 444, 337-342. [CrossRef]

89. Wang, H.; Guan, Y.; Karamercan, M.A.; Ye, L.; Bhatti, T.; Becker, L.B.; Baur, J.A.; Sims, C.A. Resveratrol Rescues Kidney Mitochondrial Function Following Hemorrhagic Shock. Shock 2015, 44, 173-180. [CrossRef]

90. Price, N.L.; Gomes, A.P.; Ling, A.J.; Duarte, F.V.; Martin-Montalvo, A.; North, B.J.; Agarwal, B.; Ye, L.; Ramadori, G.; Teodoro, J.S.; et al. SIRT1 is required for AMPK activation and the beneficial effects of resveratrol on mitochondrial function. Cell Metab. 2012, 15, 675-690. [CrossRef]

91. Di Pierro, F.; Bressan, A.; Ranaldi, D.; Rapacioli, G.; Giacomelli, L.; Bertuccioli, A. Potential role of bioavailable curcumin in weight loss and omental adipose tissue decrease: Preliminary data of a randomized, controlled trial in overweight people with metabolic syndrome. Preliminary study. Eur. Rev. Med. Pharm. Sci. 2015, 19, 4195-4202.

92. Kunnumakkara, A.B.; Bordoloi, D.; Padmavathi, G.; Monisha, J.; Roy, N.K.; Prasad, S.; Aggarwal, B.B. Curcumin, the golden nutraceutical: Multitargeting for multiple chronic diseases. Br. J. Pharm. 2017, 174, 1325-1348. [CrossRef] [PubMed]

93. Qin, S.; Huang, L.; Gong, J.; Shen, S.; Huang, J.; Ren, H.; Hu, H. Efficacy and safety of turmeric and curcumin in lowering blood lipid levels in patients with cardiovascular risk factors: A meta-analysis of randomized controlled trials. Nutr. J. 2017, 16, 68. [CrossRef] [PubMed]

94. Sahebkar, A.; Cicero, A.F.G.; Simental-Mendia, L.E.; Aggarwal, B.B.; Gupta, S.C. Curcumin downregulates human tumor necrosis factor-alpha levels: A systematic review and meta-analysis ofrandomized controlled trials. Pharm. Res. 2016, 107, $234-242$. [CrossRef] [PubMed] 
95. Mousavi, S.M.; Milajerdi, A.; Varkaneh, H.K.; Gorjipour, M.M.; Esmaillzadeh, A. The effects of curcumin supplementation on body weight, body mass index and waist circumference: A systematic review and dose-response meta-analysis of randomized controlled trials. Crit. Rev. Food Sci. Nutr. 2020, 60, 171-180. [CrossRef] [PubMed]

96. Saraf-Bank, S.; Ahmadi, A.; Paknahad, Z.; Maracy, M.; Nourian, M. Effects of curcumin supplementation on markers of inflammation and oxidative stress among healthy overweight and obese girl adolescents: A randomized placebo-controlled clinical trial. Phytother. Res. 2019, 33, 2015-2022. [CrossRef] [PubMed]

97. Baum, L.; Cheung, S.K.; Mok, V.C.; Lam, L.C.; Leung, V.P.; Hui, E.; Ng, C.C.; Chow, M.; Ho, P.C.; Lam, S.; et al. Curcumin effects on blood lipid profile in a 6-month human study. Pharm. Res. 2007, 56, 509-514. [CrossRef]

98. Ganjali, S.; Sahebkar, A.; Mahdipour, E.; Jamialahmadi, K.; Torabi, S.; Akhlaghi, S.; Ferns, G.; Parizadeh, S.M.; Ghayour-Mobarhan, M. Investigation of the effects of curcumin on serum cytokines in obese individuals: A randomized controlled trial. Sci. World J. 2014, 2014, 898361. [CrossRef]

99. Shao, W.; Yu, Z.; Chiang, Y.; Yang, Y.; Chai, T.; Foltz, W.; Lu, H.; Fantus, I.G.; Jin, T. Curcumin prevents high fat diet induced insulin resistance and obesity via attenuating lipogenesis in liver and inflammatory pathway in adipocytes. PLoS ONE 2012, 7, e28784. [CrossRef]

100. Weisberg, S.P.; Leibel, R.; Tortoriello, D.V. Dietary curcumin significantly improves obesity-associated inflammation and diabetes in mouse models of diabesity. Endocrinology 2008, 149, 3549-3558. [CrossRef]

101. Ahn, J.; Lee, H.; Kim, S.; Ha, T. Curcumin-induced suppression of adipogenic differentiation is accompanied by activation of Wnt/beta-catenin signaling. Am. J. Physiol. Cell Physiol. 2010, 298, C1510-6. [CrossRef]

102. Tian, L.; Song, Z.; Shao, W.; Du, W.W.; Zhao, L.R.; Zeng, K.; Yang, B.B.; Jin, T. Curcumin represses mouse 3T3-L1 cell adipogenic differentiation via inhibiting miR-17-5p and stimulating the Wnt signalling pathway effector Tcf712. Cell Death Dis. 2017, 8, e2559. [CrossRef] [PubMed]

103. Ejaz, A.; Wu, D.; Kwan, P.; Meydani, M. Curcumin inhibits adipogenesis in 3T3-L1 adipocytes and angiogenesis and obesity in C57/BL mice. J. Nutr. 2009, 139, 919-925. [CrossRef] [PubMed]

104. Yang, C.S.; Wang, X.; Lu, G.; Picinich, S.C. Cancer prevention by tea: Animal studies, molecular mechanisms and human relevance. Nat. Rev. Cancer 2009, 9, 429-439. [CrossRef] [PubMed]

105. Hayakawa, S.; Saito, K.; Miyoshi, N.; Ohishi, T.; Oishi, Y.; Miyoshi, M.; Nakamura, Y. Anti-Cancer Effects of Green Tea by Either Anti- or Pro- Oxidative Mechanisms. Asian Pac. J. Cancer Prev. 2016, 17, 1649-1654. [CrossRef]

106. Lewandowska, U.; Szewczyk, K.; Hrabec, E.; Janecka, A.; Gorlach, S. Overview of Metabolism and Bioavailability Enhancement of Polyphenols. J. Agric. Food Chem. 2013, 61, 12183-12199. [CrossRef]

107. Steinberg, G.R.; Michell, B.J.; van Denderen, B.J.; Watt, M.J.; Carey, A.L.; Fam, B.C.; Andrikopoulos, S.; Proietto, J.; Gorgun, C.Z.; Carling, D.; et al. Tumor necrosis factor alpha-induced skeletal muscle insulin resistance involves suppression of AMP-kinase signaling. Cell Metab. 2006, 4, 465-474. [CrossRef]

108. Gejjalagere Honnappa, C.; Mazhuvancherry Kesavan, U. A concise review on advances in development of small molecule anti-inflammatory therapeutics emphasising AMPK: An emerging target. Int. J. Immunopathol. Pharm. 2016, 29, 562-571. [CrossRef]

109. Silva, J.; Spatz, M.H.; Folk, C.; Chang, A.; Cadenas, E.; Liang, J.; Davies, D.L. Dihydromyricetin improves mitochondrial outcomes in the liver of alcohol-fed mice via the AMPK/Sirt-1/PGC-1alpha signaling axis. Alcohol 2020, 91, 1-9. [CrossRef]

110. Sakamoto, N.; Honma, R.; Sekino, Y.; Goto, K.; Sentani, K.; Ishikawa, A.; Oue, N.; Yasui, W. Non-coding RNAs are promising targets for stem cell-based cancer therapy. Noncoding RNA Res. 2017, 2, 83-87. [CrossRef]

111. Zhang, L.; Valizadeh, H.; Alipourfard, I.; Bidares, R.; Aghebati-Maleki, L.; Ahmadi, M. Epigenetic Modifications and Therapy in Chronic Obstructive Pulmonary Disease (COPD): An Update Review. COPD 2020, 17, 333-342. [CrossRef]

112. Iacomino, G.; Siani, A. Role of microRNAs in obesity and obesity-related diseases. Genes Nutr. 2017, 12, 23. [CrossRef] [PubMed]

113. Tsai, C.Y.; Chen, C.Y.; Chiou, Y.H.; Shyu, H.W.; Lin, K.H.; Chou, M.C.; Huang, M.H.; Wang, Y.F. Epigallocatechin-3-Gallate Suppresses Human Herpesvirus 8 Replication and Induces ROS Leading to Apoptosis and Autophagy in Primary Effusion Lymphoma Cells. Int. J. Mol. Sci. 2017, 19, 16. [CrossRef] [PubMed]

114. Hsieh, C.H.; Lu, C.H.; Kuo, Y.Y.; Chen, W.T.; Chao, C.Y. Studies on the non-invasive anticancer remedy of the triple combination of epigallocatechin gallate, pulsed electric field, and ultrasound. PLoS ONE 2018, 13, e0201920. [CrossRef] [PubMed]

115. Liu, J.; Lu, Y.; Liu, J.; Jin, C.; Meng, Y.; Pei, D. Influence of epigallocatechin-3-gallate in promoting proliferation and osteogenic differentiation of human periodontal ligament cells. BMC Oral. Health 2019, 19, 73. [CrossRef] [PubMed]

116. Tan, Y.; Kim, J.; Cheng, J.; Ong, M.; Lao, W.G.; Jin, X.L.; Lin, Y.G.; Xiao, L.; Zhu, X.Q.; Qu, X.Q. Green tea polyphenols ameliorate non-alcoholic fatty liver disease through upregulating AMPK activation in high fat fed Zucker fatty rats. World J. Gastroenterol. 2017, 23, 3805-3814. [CrossRef] [PubMed]

117. Bae, U.J.; Park, J.; Park, I.W.; Chae, B.M.; Oh, M.R.; Jung, S.J.; Ryu, G.S.; Chae, S.W.; Park, B.H. Epigallocatechin-3-Gallate-Rich Green Tea Extract Ameliorates Fatty Liver and Weight Gain in Mice Fed a High Fat Diet by Activating the Sirtuin 1 and AMP Activating Protein Kinase Pathway. Am. J. Chin. Med. 2018, 46, 617-632. [CrossRef]

118. Ueda-Wakagi, M.; Hayashibara, K.; Nagano, T.; Ikeda, M.; Yuan, S.; Ueda, S.; Shirai, Y.; Yoshida, K.I.; Ashida, H. Epigallocatechin gallate induces GLUT4 translocation in skeletal muscle through both PI3K- and AMPK-dependent pathways. Food Funct. 2018, 9 , 4223-4233. [CrossRef]

119. Wada, Y.; Takata, A.; Ikemoto, T.; Morine, Y.; Imura, S.; Iwahashi, S.; Saito, Y.; Shimada, M. The protective effect of epigallocatechin 3-gallate on mouse pancreatic islets via the Nrf2 pathway. Surg. Today 2019, 49, 536-545. [CrossRef] 
120. Qin, S.; Chen, M.H.; Fang, W.; Tan, X.F.; Xie, L.; Yang, Y.G.; Qin, T.; Li, N. Cerebral protection of epigallocatechin gallate (EGCG) via preservation of mitochondrial function and ERK inhibition in a rat resuscitation model. Drug Des. Dev. 2019, 13, 2759-2768. [CrossRef]

121. Yi, J.; Chen, C.; Liu, X.; Kang, Q.; Hao, L.; Huang, J.; Lu, J. Radioprotection of EGCG based on immunoregulatory effect and antioxidant activity against (60)Cogamma radiation-induced injury in mice. Food Chem. Toxicol. 2020, 135, 111051. [CrossRef]

122. Zhong, X.; Liu, M.; Yao, W.; Du, K.; He, M.; Jin, X.; Jiao, L.; Ma, G.; Wei, B.; Wei, M. Epigallocatechin-3-Gallate Attenuates Microglial Inflammation and Neurotoxicity by Suppressing the Activation of Canonical and Noncanonical Inflammasome via TLR4/NF-kappaB Pathway. Mol. Nutr. Food Res. 2019, 63, e1801230. [CrossRef] [PubMed]

123. Wang, F.; Han, Y.; Xi, S.; Lu, Y. Catechins reduce inflammation in lipopolysaccharide-stimulated dental pulp cells by inhibiting activation of the NF-kappaB pathway. Oral. Dis. 2020, 26, 815-821. [CrossRef] [PubMed]

124. Reddy, A.T.; Lakshmi, S.P.; Maruthi Prasad, E.; Varadacharyulu, N.C.; Kodidhela, L.D. Epigallocatechin gallate suppresses inflammation in human coronary artery endothelial cells by inhibiting NF-kappaB. Life Sci. 2020, 258, 118136. [CrossRef] [PubMed]

125. Rakshit, S.; Mandal, L.; Pal, B.C.; Bagchi, J.; Biswas, N.; Chaudhuri, J.; Chowdhury, A.A.; Manna, A.; Chaudhuri, U.; Konar, A.; et al. Involvement of ROS in chlorogenic acid-induced apoptosis of Bcr-Abl+ CML cells. Biochem. Pharm. 2010, 80, 1662-1675. [CrossRef] [PubMed]

126. Yang, J.S.; Liu, C.W.; Ma, Y.S.; Weng, S.W.; Tang, N.Y.; Wu, S.H.; Ji, B.C.; Ma, C.Y.; Ko, Y.C.; Funayama, S.; et al. Chlorogenic acid induces apoptotic cell death in U937 leukemia cells through caspase- and mitochondria-dependent pathways. Vivo 2012, 26, 971-978.

127. Zhou, Y.; Ruan, Z.; Zhou, L.; Shu, X.; Sun, X.; Mi, S.; Yang, Y.; Yin, Y. Chlorogenic acid ameliorates endotoxin-induced liver injury by promoting mitochondrial oxidative phosphorylation. Biochem. Biophys. Res. Commun. 2016, 469, 1083-1089. [CrossRef]

128. Jang, M.H.; Kim, K.Y.; Song, P.H.; Baek, S.Y.; Seo, H.L.; Lee, E.H.; Lee, S.G.; Park, K.I.; Ahn, S.C.; Kim, S.C.; et al. Moutan Cortex Protects Hepatocytes against Oxidative Injury through AMP-Activated Protein Kinase Pathway. Biol. Pharm. Bull. 2017, 40, 797-806. [CrossRef]

129. Tsai, K.L.; Hung, C.H.; Chan, S.H.; Hsieh, P.L.; Ou, H.C.; Cheng, Y.H.; Chu, P.M. Chlorogenic Acid Protects Against oxLDLInduced Oxidative Damage and Mitochondrial Dysfunction by Modulating SIRT1 in Endothelial Cells. Mol. Nutr. Food Res. 2018, 62, e1700928. [CrossRef]

130. Han, D.; Gu, X.; Gao, J.; Wang, Z.; Liu, G.; Barkema, H.W.; Han, B. Chlorogenic acid promotes the Nrf2/HO-1 anti-oxidative pathway by activating p21(Waf1/Cip1) to resist dexamethasone-induced apoptosis in osteoblastic cells. Free Radic. Biol. Med. 2019, 137, 1-12. [CrossRef]

131. Gong, W.; Li, J.; Zhu, G.; Wang, Y.; Zheng, G.; Kan, Q. Chlorogenic acid relieved oxidative stress injury in retinal ganglion cells through IncRNA-TUG1/Nrf2. Cell Cycle 2019, 18, 1549-1559. [CrossRef]

132. Kong, D.; Ding, Y.; Liu, J.; Liu, R.; Zhang, J.; Zhou, Q.; Long, Z.; Peng, J.; Li, L.; Bai, H.; et al. Chlorogenic acid prevents paraquat-induced apoptosis via Sirt1-mediated regulation of redox and mitochondrial function. Free Radic. Res. 2019, 53, 680-693. [CrossRef] [PubMed]

133. Bao, L.; Li, J.; Zha, D.; Zhang, L.; Gao, P.; Yao, T.; Wu, X. Chlorogenic acid prevents diabetic nephropathy by inhibiting oxidative stress and inflammation through modulation of the Nrf2/HO-1 and NF-kB pathways. Int. Immunopharmacol. 2018, 54, 245-253. [CrossRef] [PubMed]

134. Tian, L.; Su, C.P.; Wang, Q.; Wu, F.J.; Bai, R.; Zhang, H.M.; Liu, J.Y.; Lu, W.J.; Wang, W.; Lan, F.; et al. Chlorogenic acid: A potent molecule that protects cardiomyocytes from TNF-alpha-induced injury via inhibiting NF-kappaB and JNK signals. J. Cell Mol. Med. 2019, 23, 4666-4678. [CrossRef] [PubMed]

135. Fu, X.; Lyu, X.; Liu, H.; Zhong, D.; Xu, Z.; He, F.; Huang, G. Chlorogenic Acid Inhibits BAFF Expression in Collagen-Induced Arthritis and Human Synoviocyte MH7A Cells by Modulating the Activation of the NF-kappaB Signaling Pathway. J. Immunol. Res. 2019, 2019, 8042097. [CrossRef] [PubMed]

136. Posadino, A.M.; Giordo, R.; Cossu, A.; Nasrallah, G.K.; Shaito, A.; Abou-Saleh, H.; Eid, A.H.; Pintus, G. Flavin Oxidase-Induced ROS Generation Modulates PKC Biphasic Effect of Resveratrol on Endothelial Cell Survival. Biomolecules 2019, 9, 209. [CrossRef]

137. Chen, C.Y.; Kao, C.L.; Liu, C.M. The Cancer Prevention, Anti-Inflammatory and Anti-Oxidation of Bioactive Phytochemicals Targeting the TLR4 Signaling Pathway. Int. J. Mol. Sci. 2018, 19, 2729. [CrossRef]

138. Li, C.; Hu, W.L.; Lu, M.X.; Xiao, G.F. Resveratrol induces apoptosis of benign prostatic hyperplasia epithelial cell line (BPH-1) through p38 MAPK-FOXO3a pathway. BMC Complement. Altern. Med. 2019, 19, 233. [CrossRef]

139. Vlavcheski, F.; Den Hartogh, D.J.; Giacca, A.; Tsiani, E. Amelioration of High-Insulin-Induced Skeletal Muscle Cell Insulin Resistance by Resveratrol Is Linked to Activation of AMPK and Restoration of GLUT4 Translocation. Nutrients 2020, 12, 914. [CrossRef]

140. Guo, J.; Pereira, T.J.; Mori, Y.; Gonzalez Medina, M.; Breen, D.M.; Dalvi, P.S.; Zhang, H.; McCole, D.F.; McBurney, M.W.; Heximer, S.P.; et al. Resveratrol Inhibits Neointimal Growth after Arterial Injury in High-Fat-Fed Rodents: The Roles of SIRT1 and AMPK. J. Vasc. Res. 2020, 57, 325-340. [CrossRef]

141. Wang, L.; Li, Q.; Yan, H.; Jiao, G.; Wang, H.; Chi, H.; Zhou, H.; Chen, L.; Shan, Y.; Chen, Y. Resveratrol Protects Osteoblasts Against Dexamethasone-Induced Cytotoxicity Through Activation of AMP-Activated Protein Kinase. Drug Des. Dev. 2020, 14, 4451-4463. [CrossRef] 
142. Giordo, R.; Nasrallah, G.K.; Al-Jamal, O.; Paliogiannis, P.; Pintus, G. Resveratrol Inhibits Oxidative Stress and Prevents Mitochondrial Damage Induced by Zinc Oxide Nanoparticles in Zebrafish (Danio rerio). Int. J. Mol. Sci. 2020, 21, 3838. [CrossRef] [PubMed]

143. Ramdani, L.H.; Bachari, K. Potential therapeutic effects of Resveratrol against SARS-CoV-2. Acta Virol. 2020, 64, 276-280. [CrossRef] [PubMed]

144. Zhang, W.; Tang, R.; Ba, G.; Li, M.; Lin, H. Anti-allergic and anti-inflammatory effects of resveratrol via inhibiting TXNIP-oxidative stress pathway in a mouse model of allergic rhinitis. World Allergy Organ. J. 2020, 13, 100473. [CrossRef] [PubMed]

145. Andre, D.M.; Calixto, M.C.; Sollon, C.; Alexandre, E.C.; Tavares, E.B.G.; Naime, A.C.A.; Anhe, G.F.; Antunes, E. High-fat diet-induced obesity impairs insulin signaling in lungs of allergen-challenged mice: Improvement by resveratrol. Sci. Rep. 2017, 7, 17296. [CrossRef] [PubMed]

146. Subedi, L.; Baek, S.H.; Kim, S.Y. Genetically Engineered Resveratrol-Enriched Rice Inhibits Neuroinflammation in Lipopolysaccharide-Activated BV2 Microglia Via Downregulating Mitogen-Activated Protein Kinase-Nuclear Factor Kappa B Signaling Pathway. Oxid. Med. Cell Longev. 2018, 2018, 8092713. [CrossRef] [PubMed]

147. Xian, Y.; Gao, Y.; Lv, W.; Ma, X.; Hu, J.; Chi, J.; Wang, W.; Wang, Y. Resveratrol prevents diabetic nephropathy by reducing chronic inflammation and improving the blood glucose memory effect in non-obese diabetic mice. Naunyn Schmiedebergs Arch. Pharm. 2020, 393, 2009-2017. [CrossRef] [PubMed]

148. Liang, H.H.; Huang, C.Y.; Chou, C.W.; Makondi, P.T.; Huang, M.T.; Wei, P.L.; Chang, Y.J. Heat shock protein 27 influences the anti-cancer effect of curcumin in colon cancer cells through ROS production and autophagy activation. Life Sci. 2018, 209 , 43-51. [CrossRef]

149. Yu, T.; Dohl, J.; Elenberg, F.; Chen, Y.; Deuster, P. Curcumin induces concentration-dependent alterations in mitochondrial function through ROS in C2C12 mouse myoblasts. J. Cell Physiol. 2019, 234, 6371-6381. [CrossRef]

150. Nakamae, I.; Morimoto, T.; Shima, H.; Shionyu, M.; Fujiki, H.; Yoneda-Kato, N.; Yokoyama, T.; Kanaya, S.; Kakiuchi, K.; Shirai, T.; et al. Curcumin Derivatives Verify the Essentiality of ROS Upregulation in Tumor Suppression. Molecules 2019, $24,4067$. [CrossRef]

151. Soltani, A.; Salmaninejad, A.; Jalili-Nik, M.; Soleimani, A.; Javid, H.; Hashemy, S.I.; Sahebkar, A. $5^{\prime}$-Adenosine monophosphateactivated protein kinase: A potential target for disease prevention by curcumin. J. Cell Physiol. 2019, 234, 2241-2251. [CrossRef]

152. Lu, X.; Wu, F.; Jiang, M.; Sun, X.; Tian, G. Curcumin ameliorates gestational diabetes in mice partly through activating AMPK. Pharm. Biol. 2019, 57, 250-254. [CrossRef] [PubMed]

153. Yu, H.; Xie, Y.; Zhou, Z.; Wu, Z.; Dai, X.; Xu, B. Curcumin Regulates the Progression of Colorectal Cancer via LncRNA NBR2/AMPK Pathway. Technol. Cancer Res. Treat. 2019, 18, 1533033819870781. [CrossRef] [PubMed]

154. Sadeghi, A.; Rostamirad, A.; Seyyedebrahimi, S.; Meshkani, R. Curcumin ameliorates palmitate-induced inflammation in skeletal muscle cells by regulating JNK/NF-kB pathway and ROS production. Inflammopharmacology 2018, 26, 1265-1272. [CrossRef] [PubMed]

155. Ran, Z.; Zhang, Y.; Wen, X.; Ma, J. Curcumin inhibits high glucoseinduced inflammatory injury in human retinal pigment epithelial cells through the ROSPI3K/AKT/mTOR signaling pathway. Mol. Med. Rep. 2019, 19, 1024-1031.

156. Lin, X.; Bai, D.; Wei, Z.; Zhang, Y.; Huang, Y.; Deng, H.; Huang, X. Curcumin attenuates oxidative stress in RAW264.7 cells by increasing the activity of antioxidant enzymes and activating the Nrf2-Keap1 pathway. PLoS ONE 2019, 14, e0216711. [CrossRef]

157. Li, Q.; Sun, J.; Mohammadtursun, N.; Wu, J.; Dong, J.; Li, L. Curcumin inhibits cigarette smoke-induced inflammation via modulating the PPARgamma-NF-kappaB signaling pathway. Food Funct. 2019, 10, 7983-7994. [CrossRef]

158. Khan, M.S.; Muhammad, T.; Ikram, M.; Kim, M.O. Dietary Supplementation of the Antioxidant Curcumin Halts Systemic LPSInduced Neuroinflammation-Associated Neurodegeneration and Memory/Synaptic Impairment via the JNK/NF-kappaB/Akt Signaling Pathway in Adult Rats. Oxid. Med. Cell Longev. 2019, 2019, 7860650. [CrossRef]

159. Zhou, T.; Wang, Y.; Liu, M.; Huang, Y.; Shi, J.; Dong, N.; Xu, K. Curcumin inhibits calcification of human aortic valve interstitial cells by interfering NF-kappaB, AKT, and ERK pathways. Phytother. Res. 2020, 34, 2074-2081. [CrossRef]

160. Mirzaaghaei, S.; Foroughmand, A.M.; Saki, G.; Shafiei, M. Combination of Epigallocatechin-3-gallate and Silibinin: A Novel Approach for Targeting Both Tumor and Endothelial Cells. ACS Omega 2019, 4, 8421-8430. [CrossRef]

161. Huang, S.; Wang, L.L.; Xue, N.N.; Li, C.; Guo, H.H.; Ren, T.K.; Zhan, Y.; Li, W.B.; Zhang, J.; Chen, X.G.; et al. Chlorogenic acid effectively treats cancers through induction of cancer cell differentiation. Theranostics 2019, 9, 6745-6763. [CrossRef]

162. Pan, J.; Shen, J.; Si, W.; Du, C.; Chen, D.; Xu, L.; Yao, M.; Fu, P.; Fan, W. Resveratrol promotes MICA/B expression and natural killer cell lysis of breast cancer cells by suppressing c-Myc/miR-17 pathway. Oncotarget 2017, 8, 65743-65758. [CrossRef] [PubMed]

163. Chen, J.; Du, L.; Li, J.; Song, H. Epigallocatechin-3-gallate attenuates cadmium-induced chronic renal injury and fibrosis. Food Chem. Toxicol. 2016, 96, 70-78. [CrossRef] [PubMed]

164. Yang, F.; Luo, L.; Zhu, Z.D.; Zhou, X.; Wang, Y.; Xue, J.; Zhang, J.; Cai, X.; Chen, Z.L.; Ma, Q.; et al. Chlorogenic Acid Inhibits Liver Fibrosis by Blocking the miR-21-Regulated TGF-beta1/Smad7 Signaling Pathway in Vitro and in Vivo. Front. Pharm. 2017, 8, 929. [CrossRef] [PubMed]

165. Yan, B.; Cheng, L.; Jiang, Z.; Chen, K.; Zhou, C.; Sun, L.; Cao, J.; Qian, W.; Li, J.; Shan, T.; et al. Resveratrol Inhibits ROS-Promoted Activation and Glycolysis of Pancreatic Stellate Cells via Suppression of miR-21. Oxid. Med. Cell Longev. 2018, $2018,1346958$. [CrossRef] [PubMed] 
166. Nozari, E.; Moradi, A.; Samadi, M. Effect of Atorvastatin, Curcumin, and Quercetin on miR-21 and miR-122 and their correlation with TGFbeta1 expression in experimental liver fibrosis. Life Sci. 2020, 259, 118293. [CrossRef]

167. Liu, S.; Wu, Z.; Guo, S.; Meng, X.; Chang, X. Polyphenol-rich extract from wild Lonicera caerulea berry reduces cholesterol accumulation by mediating the expression of hepatic miR-33 and miR-122, HMGCR, and CYP7A1 in rats. J. Funct. Foods 2018, 40, 648-658. [CrossRef]

168. Zhong, Y.; Liu, C.; Feng, J.; Li, J.F.; Fan, Z.C. Curcumin affects ox-LDL-induced IL-6, TNF-alpha, MCP-1 secretion and cholesterol efflux in THP-1 cells by suppressing the TLR4/NF-kappaB/miR33a signaling pathway. Exp. Med. 2020, 20, $1856-1870$.

169. Zhang, S.; Tang, D.; Zang, W.; Yin, G.; Dai, J.; Sun, Y.U.; Yang, Z.; Hoffman, R.M.; Guo, X. Synergistic Inhibitory Effect of Traditional Chinese Medicine Astragaloside IV and Curcumin on Tumor Growth and Angiogenesis in an Orthotopic Nude-Mouse Model of Human Hepatocellular Carcinoma. Anticancer Res. 2017, 37, 465-473. [CrossRef]

170. La, X.; Zhang, L.; Li, Z.; Li, H.; Yang, Y. (-)-Epigallocatechin Gallate (EGCG) Enhances the Sensitivity of Colorectal Cancer Cells to 5-FU by Inhibiting GRP78/NF-kappaB/miR-155-5p/MDR1 Pathway. J. Agric. Food Chem. 2019, 67, 2510-2518. [CrossRef]

171. Zeng, J.; Zhang, D.; Wan, X.; Bai, Y.; Yuan, C.; Wang, T.; Yuan, D.; Zhang, C.; Liu, C. Chlorogenic Acid Suppresses miR-155 and Ameliorates Ulcerative Colitis through the NF-kappaB/NLRP3 Inflammasome Pathway. Mol. Nutr. Food Res. 2020,64, e2000452. [CrossRef]

172. Eseberri, I.; Lasa, A.; Miranda, J.; Gracia, A.; Portillo, M.P. Potential miRNA involvement in the anti-adipogenic effect of resveratrol and its metabolites. PLoS ONE 2017, 12, e0184875. [CrossRef] [PubMed]

173. Ma, F.; Liu, F.; Ding, L.; You, M.; Yue, H.; Zhou, Y.; Hou, Y. Anti-inflammatory effects of curcumin are associated with down regulating microRNA-155 in LPS-treated macrophages and mice. Pharm. Biol. 2017, 55, 1263-1273. [CrossRef] [PubMed]

174. Liu, C.W.; Sung, H.C.; Lin, S.R.; Wu, C.W.; Lee, C.W.; Lee, I.T.; Yang, Y.F.; Yu, I.S.; Lin, S.W.; Chiang, M.H.; et al. Resveratrol attenuates ICAM-1 expression and monocyte adhesiveness to TNF-alpha-treated endothelial cells: Evidence for an anti-inflammatory cascade mediated by the miR-221/222/AMPK/p38/NF-kappaB pathway. Sci. Rep. 2017, 7, 44689. [CrossRef] [PubMed] 